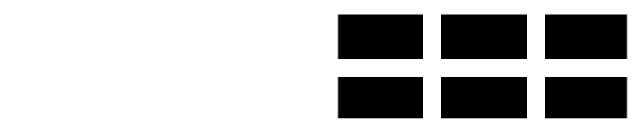

THE WILLIAM DAVIDSON INSTITUTE AT THE UNIVERSITY OF MICHIGAN BUSINESS SCHOOL

\title{
The Life Cycle of Government Ownership
}

\author{
By: Jiahua Che
}

William Davidson Institute Working Paper Number 627

October 2003 


\title{
The Life Cycle of Government Ownership
}

\author{
Jiahua Che* \\ Department of Economics \\ University of Illinois at Urbana Champaign \\ Urbana, IL 61801 \\ che@uiuc.edu
}

September 5, 2003

\begin{abstract}
Government ownership may dominate private ownership under government failure. Such dominance disappears as product markets grow mature, giving rise to the need for privatization. Buyers' limited wealth imposes a constraint on how and when privatization takes place. In particular, firms may be underpriced during privatization, and privatization may take place at a sub-optimal timing which results in firm performances to deteriorate in the short run, and to improve only in the long run. Partial privatization may alleviate the constraint in some cases but exacerbates the efficiency loss in others. When the government is lesser an interventionist or when the product market grows mature very rapidly, privatization is likely to take place at a sub-optimal timing. The analysis is applied to the dynamics of the Chinese non-state sector.
\end{abstract}

Keywords: government rent seeking, government ownership, privatization JEL Classification: P30, L20, K40

\footnotetext{
${ }^{*}$ I would like to thank the Center for International Business and Economics Research (College of Business) and the Center for East Asian and Pacific Studies at the University of Illinois for financial support. I started the project when I was visiting Euro Asia Center, INSEAD to which I am grateful for providing me a wonderful research facility. I have benefited from seminar participants at INSEAD and the University of Illinois, Loren Brandt, Giovanni Fachinni, Hongbin Li, Wei Li, and George Pinteris for their useful comments.
} 


\section{Introduction}

Recent decades have seen a wave of privatization sweeping around the world. This policy trend opens up fresh perspectives regarding government ownership. Market failure is no longer viewed as a reason that automatically warrants government ownership. Increasingly, government failure is being considered as a major factor that renders government ownership undesirable (Shleifer 1998, World Bank 1995).

However, just as market failure does not automatically warrant government ownership, government failure does not automatically warrant private ownership either. The point of departure of this paper is to demonstrate a trade-off between government and private ownership under government failure, and how the nature of this trade-off is determined by the extent of market failure. Based upon this normative analysis, the paper examines how privatization takes place in equilibrium as a result of market development, with a focus on the impact of buyers' wealth constraints. This analysis allows a number of issues pertinent to the privatization literature to be addressed in a coherent framework. These issues include: whether privatization improves firm performances, why firms are underpriced during privatization, and whether partial privatization is a "second best" instrument in the presence of wealth constraints.

A few caveats are necessary to put this analysis in perspective. The question of whether, or perhaps more precisely, under what conditions, private ownership is more efficient than government ownership is a complicated one. So are issues concerning privatization. Answers to these questions depend on the particular institutional environment, as well as firm characteristics with regard to which these questions are placed; and there ought to be no analysis that is "one-size-fits-all". My analysis in this paper makes special reference to transition from central planning to market economy. Within this context, the institutional assumptions adopted in this paper concerning government failure, buyers' wealth constraints, and markets that are gradually evolving seem to be fitting.

My analysis is carried out in two integral parts. The first part highlights the aforementioned trade-off in a static model. In this model, a firm is represented by an investment project that relies on efforts from a private agent, referred to as a manager, and an intermediate product controlled by a government agency. Government failure takes the form of a rent seeking activity by the corrupt government agency. Using its control of the intermediate product, the government agency tries to extract rents from the manager once the manager's effort is sunk, creating a standard hold-up problem (Grossman and Hart 1986 and Hart and Moore 1990). The severity of this hold-up problem depends in part upon the manager's ability to find substitutes for the intermediate product on a product market. This ability is determined by the the extent of market failure, modelled in this paper as a search-type friction.

I show that, by subjecting the financial interests of the government agency to the firm, 
government ownership induces the government agency to self-restrain its rent seeking activity. As a result, government ownership may improve the manager's incentive. I refer to this as the commitment effect of government ownership. Government ownership also allows the government agency to advance its own political interests by intervening in the business operation of the firm (Shleifer and Vishny 1994 and Boycko, Shleifer and Vishny 1996). This distortional effect and the commitment effect constitute the trade-off between government ownership and private ownership. The extend of market failure affects the manager's outside option, which in turn determines the nature of this trade-off. In particular, government ownership dominates private ownership when the product market is heavily underdeveloped, and yet such dominance disappears and private ownership becomes more efficient as the market grows mature.

This part of my analysis is closely related to Shleifer and Vishny (1994) and Boycko, Shleifer and Vishny (1996), which highlight the benefit of private ownership under government failure. According to these authors, private ownership helps prevent the government from interfering with the operation of the firm. They assume implicitly that the firm can operate efficiently without the presence of the government. In contrast, this paper considers an environment where the market is highly underdeveloped and the firm cannot operate without the government agency providing inputs under their control.

Che and Qian (1998b) makes a similar argument that (local) government ownership may dominate private ownership under government failure. In that paper, government failure takes the form of state predation and as a result property rights are fundamentally insecure. In this paper, government failure takes the form of government rent seeking whereas property rights remain secure. In that paper, the state restrains itself from predation when the firm is owned by a third party: a local government. In this paper, the government agency restrains itself from rent seeking when the firm is owned by itself.

The commitment effect of government ownership differs from the standard prediction in the property rights literature (Grossman and Hart 1986 and Hart and Moore 1990). The standard prediction suggests that allocating ownership rights to a party increases the party's bargaining power. This paper assumes that the government agency has no productive role in the firm. However, because of this commitment effect, government ownership reduces the willingness of the government agency to exercise its bargaining power. As a result, allocating ownership rights away from the party whose effort is crucial to the investment (i.e., the manager) can actually enhance the latter's incentive. ${ }^{1}$

The second part of my analysis extends the static model into a dynamic one where the

\footnotetext{
${ }^{1}$ This observation is reminiscent to Chiu (1998) and De Meza and Lockwood (1998). Different from Chiu (1998) and De Meza and Lockwood (1998), it is derived from an argument based on the fact that ownership form can change the information value (without changing the information structure). See the next section for a more detailed discussion.
} 
product market matures overtime (exogenously). My analysis focuses on how privatization takes place endogenously in response to the product market development. By integrating the normative and the positive aspects of privatization, this paper avoids the typical assumption that government ownership is less efficient and privatization is a must, and is able to compare the equilibrium timing of privatization with the optimal timing of privatization, a comparison that is essential for what this paper sets out to address.

I limit my discussion to insider-privatization, that is, privatization to the manager in the context of this paper. Such a focus may be rationalized in the context of small-medium sized firms, where empowering insiders, in particular the management, and stemming government intervention rather than infusing fresh capital have been the major drive for privatization. With reference to transition economies, I emphasize buyers' (i.e., the manager's) limited wealth as one of the major constraints during privatization (Bolton and Roland 1992 and Roland 2000).

Following the first part of my analysis, I characterize how payoffs for both the manager and the government agency under the two ownership forms evolve along with the product market development. Privatization takes place when the government agency and the manager, who is wealth constrained, reaches an agreement through bargaining. To entertain a conventional wisdom that partial privatization is the "second best" instrument in dealing with the wealth constraint, I also differentiate privatization into full and partial. Under full privatization, the government agency relinquishes both control and its share of investment returns; whereas under partial privatization, the government agency maintains its share of investment returns.

I present three main results in this part of my analysis. My first result corresponds to an intensive debate in the privatization literature: Does privatization improve firm performance? Surveying existing empirical works, Bevan, Estrin, and Schaffer (1999) suggests that there is no systematically significant effect of privatization on performance; while Djankov, Simeon and Peter Murrell (2002) feels confident that privatization improves performance. Meanwhile, the dubious post-privatization performance has been attributed to various policy failures during privatization, especially the lack of in-depth institutional reforms (Aghion and Blanchard 1998, Debande and Friebel 1999, Zinnes, Eilat, and Sachs 2001). I show that when the manager's wealth constraint is binding at the optimal timing of privatization, privatization will take place prematurely, that is, before the product market development has reached a state that private ownership dominates government ownership. Consequently, as a transitory phenomenon in equilibrium, the firm performance may deteriorate immediately after privatization, but will improve in the long run as the product market develops further. My reasoning thus complements the argument that lack of institutional reform is to blame for the performance shortfall. On the one hand, the post-privatization performance deterioration happens because privatization takes place before the product market matures. On the other hand, my analysis also shows that, even with in-depth institutional reform coming in the 
future, a rent-seeking minded government may still strategically privatize the firm before the reform is in place.

The second result of my privatization analysis relates the manager's wealth constraint to the underpricing phenomenon. In the privatization literature that relates to economic transition, underpricing is typically referred to as a phenomenon in share-issue privatization, typically to outsiders. There are two main arguments in this literature. One is a political economy argument advanced by Biais and Perotti (2002), suggesting that underpricing helps create a large political base to avoid any post-privatization expropriation (Schmidt 2000). The other is an information argument offered by Bolton, Pivetta, and Roland (1997), according to which underpricing (along with partial privatization) can be used to sort out new owners' ability in managing the firm. Focusing on insider privatization, this paper provides an alternative explanation for underpricing. ${ }^{2}$ In this paper, underpricing is defined as the sale price of the firm not exhausting neither the manager's ability nor his willingness to pay. I show that, when the manager's wealth constraint is binding off-equilibrium, the bargaining power of the government agency will be weakened in equilibrium, which in turn leads to underpricing.

My third result concerns the efficiency implication of partial privatization. In the presence of buyers' wealth constraints, partial privatization is a natural candidate as a policy instrument to circumvent such constraints (Bolton and Roland 1992 and Roland 2000). Furthermore, the existing literature has shown that partial privatization can help overcome various constraints in addition to buyers' limited wealth. ${ }^{3}$ Partial privatization appears to be a "second best" instrument in dealing with these constraints during privatization. My analysis re-evaluates the impact of partial privatization within the context of buyers' wealth constraints. By allowing the government agency to choose between full and partial privatization, I show partial privatization as "a double-edged sward". On the one hand, partial privatization helps enhance the government agency's stake in ownership transformation, thus may help relieve the constraint imposed by the manager's limited wealth. However, the possibility to partially privatize the firm also shifts the government agency's threat point during full privatization. It therefore also helps enhance the government agency's bargaining power and, in the presence of the manager's wealth constraint, induces the government agency to distort both the timing and the method of privatization. My analysis thus serves as a cautionary reminder that partial privatization may exacerbate rather than reduce efficiency loss caused by buyers' limited wealth during privatization.

\footnotetext{
${ }^{2}$ In the case of privatizing small and medium-sized enterprises to firm insiders, which often times are initiated by local governments in a decentralized fashion (see Cao, Qian, and Weingast 1999 for the account of China), the political economy concern and the problem of information asymmetry are arguably less prominent than in the case of large-scale privatization, typically carried out by the central government.

${ }^{3}$ For instance, Perotti (1995) argues that partial privatization can help build political confidence in reform, Demougin and Sinn (1994) suggests that it offers risk-sharing, and Bolton, Pivetta, and Roland (1997) proposes partial privatization (along with underpricing) as a sorting mechanism to overcome information asymmetry in privatization.
} 
The rest of the paper is organized as follows. Section 2 introduces the static model and the trade-off between government and private ownership is analyzed in section 3 . In section 4, I traces out how the payoffs for the government agency and the manager evolve along with the product market development. This analysis allows me to identify the optimal timing of privatization. In the subsequent two sections, I analyze how privatization takes place in equilibrium when the manager has limited wealth. I begin with the case where partial privatization is not an option for the government agency. I use this case to examine the issue of underpricing and the relation between privatization and firm performance. I then proceed with the case where the government agency can choose between full and partial privatization and demonstrate why partial privatization may exacerbate efficiency loss. In the concluding section, I relate my analysis to the case of China and discuss how this paper, both in terms of its assumptions and its analysis, fits the experience of China over the recent years. Additional results and some possible extensions are discussed as well.

\section{The Baseline Model}

The baseline model is static and involves one period only. There are two risk-neutral agents in this model: a manager of a firm and a government agency. The firm is characterized as an investment project that requires an intermediate product and efforts from the manager, both ex ante and ex post, that is, both before and after the intermediate product is acquired. The ex ante effort helps launch the project and the ex post effort helps complete it. I denote by $e$ the level of the ex ante effort, where $e \in[0,1]$, and by $a$ the level of the ex post effort, where $a \in[0,1]$. The costs of these efforts are denoted by $c(e)$ and $c(a)$ respectively.

The investment is launched with probability $e$ after the ex ante effort is undertaken. Once launched, the investment needs the intermediate product in place in order to continue. The product, which cannot be acquired before the investment is launched (perhaps because of unknown investment specifics), is subject to government regulation. Under the regulation, the government agency is charged with the authority to allocate the product at a regulated price normalized to zero. However, the government agency is corrupt, it uses its authority to illicitly collect a fee, $B$. In particular, after the investment has been initiated, the government agency makes a take-it-or-leave-it offer to the manager to pay $B$, where $B \in(-\infty, \infty)$, or the product will not be allocated. I allow the fee to be negative as the government agency may offer the manager a subsidy instead of charging him the fee. ${ }^{4}$ If the product is not allocated, the manager will approach an product market to acquire a perfect substitute at a price that is normalized to zero as well. The market is underdeveloped in the sense that the manager is

\footnotetext{
${ }^{4}$ I assume that, in the case of a subsidy, the government agency has a sufficient large fiscal budget. Che (2002) analyzes the implication when the government agency has a small fiscal budget.
} 
able to acquire the substitute with probability $\mu$ and with probability $1-\mu$, the investment has to be terminated because of the lack of the intermediate product.

If completed, the investment generates a return. The expected value of this return depends, among other things, on the product allocation. I denote by $R_{1}$ this expected value when the government-regulated product is allocated, and denote by $R_{0}$ when the substitute is used in the investment. The return on investment is not contractable and as a result, its claim depends on ownership structure. I consider two kinds of ownership structures: private ownership where the manager has the claim, and government ownership where the government agency and the manager shares the return. ${ }^{5}$ For simplicity, I do not endogenize the share, but assume instead that the government receives a share of $1-\lambda$ and the manager receives $\lambda .{ }^{6}$ The ownership form cannot be altered during the course of the investment.

The government agency can be of the following two types: one with a laissez-faire attitude towards the firm, or one that is an interventionist. At the beginning of the period, Nature draws the type and reveals to the government agency but never to the manager. I assume that the government agency's type bears no effect on the investment when the firm is privately owned, but has an impact on both the investment return as well as the productivity of the manager's ex post effort. In particular, denote by $\theta\left(\theta \in\left\{\theta_{h}, \theta_{1}\right\}\right)$ the government agency's type, $\theta=\theta_{h}$ when the government agency holds a laissez-faire attitude, and $\theta=\theta_{l}$ vice versa. The a priori belief of the manager is that $\theta=\theta_{h}$ with probability of $\gamma$ and $\theta=\theta_{l}$ with probability $1-\gamma$. Let $R_{i}=R_{i}(a \mid \theta)$ denote the expected value of the investment return under government ownership and by $R_{i}=R_{i}(a)$ the expected value under private ownership. The subscript $i$, where $i \in\{0,1\}$, indicates whether the product is allocated by the government agency $(i=1)$ or acquired from the market $(i=0)$.

Assumption 1 1) $R_{i}(a) \geq R_{i}\left(a \mid \theta_{h}\right)>R_{i}\left(a \mid \theta_{l}\right)$ for $i \in\{0,1\}$

2) $\frac{\partial R_{i}}{\partial a} \geq \frac{\partial R_{i}\left(\theta_{h}\right)}{\partial a}>\frac{\partial R_{i}\left(\theta_{l}\right)}{\partial a}$ for $i \in\{0,1\}$;

3) $R_{1}\left(a \mid \theta_{h}\right)-R_{0}\left(a \mid \theta_{h}\right) \geq R_{1}\left(a \mid \theta_{l}\right)-R_{0}\left(a \mid \theta_{l}\right)$; and

4) $R_{1}(a \mid \theta)-R_{0}(a \mid \theta)$ is non-decreasing in a for $\theta \in\left\{\theta_{h}, \theta_{1}\right\}$.

Assumption 1 formalizes the notion that the government agency has no productive role in the firm $(R(a) \geq R(a \mid \theta)$ for any $\theta),{ }^{7}$ and that the interventionist type reduces both the

\footnotetext{
${ }^{5}$ I assume for simplicity that the owner does not have control over from which source the product is acquired. Relaxing this assumption does not change my qualitative results.

${ }^{6}$ The manager shares the investment return under government ownership because he has the technological expertise necessary for the investment. One may endogenize these shares, using the framework of Grossman and Hart (1986) and Hart and Moore (1990).

${ }^{7}$ Notice that allowing the government agency to have a productive role in the firm will only strengthen the case for government ownership. Maintaining the assumption of an unproductive government thus helps sharpen my analysis.
} 
investment return and the marginal productivity of the manager as compared to the laissezfaire type. Furthermore, it implies that the laissez-faire attitude complements to the use of the government-regulated intermediate product, which also complements the ex post managerial effort.

The story behind the characterization of the government agency's types as well as the information asymmetry nature associated with these types can be told as follows. The government agency has its political agenda, such as maintaining high employment. However excessive hiring by the firm may reduce both its investment return and the productivity of the manager's ex post effort. Private ownership helps prevent the government agency from using the firm to pursue its political agenda, whereas government ownership allows the government agency to interfere (Shleifer and Vishny 1994 and Boycko, Shleifer, and Vishny 1996). However, because government interference also hurts the financial interests of the government agency as an owner under government ownership, the government agency must weigh in the balance between its financial interest and its political agenda. Such a balance is often influence by various political and economic factors the government agency faces. Many of these factors fluctuate from time to time and are better known to the government than to the general public, thus creating the information asymmetry as discussed before. It is worth mentioning that my analysis stands, as long as the manager has slightest uncertainty concerning the government agency's attitude towards the firm.

While such information asymmetry persists under both government ownership and private ownership, it matters only when the firm is government owned. This is because the government interference is unproductive and the government agency can interfere with the investment operation under private ownership. In contrast, the government agency can use its ownership right to interfere (i.e., to act upon its private information) under government ownership. In other words, ownership form changes the value of information without changing the structure of information. ${ }^{8}$ One way to formalize such a change in information value under different ownership forms is to introduce a non-contractable control decision exercisable only by the owner of the firm, as in Che (2002). To simplify the exposition, I choose a reduced form presentation by assuming directly, as in Assumption 1, that $\theta$ is neutral under private ownership but is not under government ownership.

The sequence of events in this baseline model is summarized as follows:

- Ownership of the firm is determined.

${ }^{8}$ This feature differentiates this paper from earlier works that compare government ownership with private ownership based on an information argument. For example, Schmidt (1996) argues that private ownership reduces the amount of information that politicians have, and as a result leads to a reduction of subsidies to the firm. Li (1996) suggests that the reduction of information available to a local government may prevent it from helping out the firm when the political environment becomes unfavorable. Both papers assume that the information structure changes under different ownership forms. This paper builds on these two earlier contributions but uses the assumption that information value instead of information structure changes under different ownership forms. 
- The manager chooses $e$ to launch the investment and $\theta$ is revealed to the government agency.

- The intermediate product is needed for the investment, the government agency charges $B$ for the product.

- If the government agency does not allocate the product, a substitute is acquired from the product market with probability $\mu$.

- The investment is terminated without the intermediate product or its substitute; otherwise the manager chooses $a$ to manage the investment.

- The investment return is realized and distributed according to the ownership form.

The first best outcome in the baseline model is defined as a choice of $\{e, a\}$ such that:

$$
\{e, a\}=\arg \max _{e, a} e\left(R_{1}(a)-c(a)\right)-c(e) .
$$

This outcome is implemented under private ownership if the government agency is not corrupt. I now turn to the situation where the government agency is corrupt. I proceed my analysis using sequential equilibrium as my solution concept, and I apply the intuitive criterion test (Cho and Kreps (1987)) to eliminate the "unreasonable" sequential equilibria.

\section{Government Ownership v.s. Private Ownership: The Static Trade-Off}

Under private ownership, the government agency extracts rents from the firm solely based on the fee it charges for the intermediate product. After the product is allocated, the manager chooses the ex post effort, denoted by $a_{1}^{p}$, such that $a_{1}^{p}=\arg \max \left(R_{1}(a)-c(a)\right)$. Let $w_{1}^{p}$ denote the resulting ex post payoff of the manager. Were the product not allocated, the manager would acquire a substitute with probability $\mu$, following with an ex post effort, $a_{0}^{p}$, such that $a_{0}^{p}=\arg \max \left(R_{0}(a)-c(a)\right)$. Let $w_{0}^{p}$ denote the manager's ex post payoff in this case. With all the bargaining power, the government agency will charge the fee, $B^{p}$, that drives the manager's ex post payoff down to his outside option $\mu w_{0}^{p}$, leaving the manager with zero rent. In other words,

$$
w_{1}^{p} \equiv R_{1}\left(a_{1}^{p}\right)-c\left(a_{1}^{p}\right)-B^{p}=\mu w_{0}^{p}
$$

Under government ownership, the choice of the ex post managerial effort depends on the manager's posterior belief of the government type, which in turn depends on how the government agency sets the fee. I denote by $\rho$ the posterior belief that $\theta=\theta_{h}$. Once the government-regulated product is allocated, the manager chooses the ex post effort $a_{1}^{g}(\rho)$ such that:

$$
a_{1}^{g}(\rho)=\arg \max \left[\rho \lambda R_{1}\left(a \mid \theta_{h}\right)+(1-\rho) \lambda R_{1}\left(a \mid \theta_{l}\right)-c(a)\right] .
$$


Following part 2 of Assumption $1, a_{1}^{g}(\rho)$ is increasing in $\rho$.

The government agency extracts rents from two sources under government ownership: its share of the investment return and the fee for the product. Let $B^{g}(\theta)$ denote the fee charged by the government agency of type $\theta$. The ex post payoff of the $\theta$ type government agency is:

$$
v^{g}\left(a_{1}^{g}(\rho), B^{g}(\theta) \mid \theta\right)=(1-\lambda) R_{1}\left(a_{1}^{g}(\rho) \mid \theta\right)+B^{g}(\theta) .
$$

I can establish the following single-crossing property using part 2 of Assumption 1.

Lemma 1 Suppose Assumption 1 holds. Then fixing any posterior belief $\rho$, the government agency's payoff $v^{g}(\theta) \equiv v^{g}\left(a_{1}^{g}(\rho), B^{g}(\theta) \mid \theta\right)$ satisfies the following single-crossing property:

$$
\frac{\partial v^{g}\left(\theta_{h}\right)}{\partial a_{1}^{g}} / \frac{\partial v^{g}\left(\theta_{h}\right)}{\partial B^{g}}>\frac{\partial v^{g}\left(\theta_{l}\right)}{\partial a_{1}^{g}} / \frac{\partial v^{g}\left(\theta_{l}\right)}{\partial B^{g}} .9
$$

Lemma 1 implies that a laissez-faire type government agency finds it marginally more profitable to trade-off a smaller fee for a better ex post managerial effort than a interventionist type government agency does (because the managerial effort is more productive when the government agency has a laissez-faire attitude). It further implies that there exists a separating equilibrium where $B^{g}\left(\theta_{h}\right)<B^{g}\left(\theta_{l}\right)$, which is also unique after the intuitive criterion test.

Lemma 2 Suppose that Assumption 1 hold. There exists a separating equilibrium under government ownership, where $B^{g}\left(\theta_{h}\right)<B^{g}\left(\theta_{l}\right)$ and the equilibrium is unique.

The ex post managerial effort is more productive when the government agency has a laissez-faire attitude. This, combined with the higher ex post managerial effort, implies that the return on investment is larger when the government agency is a laissez-faire type. Given that the ex post managerial effort, the laissez-faire attitude of the government agency, and the government-regulated product are all complementary to each other (part 3 and 4 of Assumption 1), more rents are appropriable by the government agency when it is laissez-faire type than when it is an interventionist. Using the truth-telling constraint for the government agency and the fact that $B^{g}\left(\theta_{h}\right)<B^{g}\left(\theta_{l}\right)$, I can then conclude that the government agency will not appropriate all the rents from the manager under government ownership, in particular when it has a laissez-faire attitude.

Proposition 1 Under private ownership, the government agency always full exercises its bargaining power and the manager never receives any rents. In contrast, suppose that Assumption 1 holds. Then under government ownership, the government agency does not fully

${ }^{9}$ All proofs, unless omitted, are relegated to the appendix. 
exercise its bargaining power when $\theta=\theta_{h}$ and the manager receives a positive amount of expected rents ex ante.

In comparison with private ownership, government ownership compromises the ex post managerial incentive. The compromise comes from two sources. On the one hand, the incentive for the ex post managerial effort is diluted because the government agency shares the investment return. And on the other hand, the productivity of the ex post managerial effort may be hampered due to the government interference. Because of such distortional effect, government ownership is dominated by private ownership ex post.

Nevertheless, as Proposition 1 suggests, government ownership may promote the ex ante managerial incentive as it induces the government agency to restrain itself from rent seeking activities when $\theta=\theta_{h}$. This is what I refer to as the ex ante commitment effect. Indeed, ex ante the manager chooses the effort $e^{g}$ under government ownership so that

$$
e^{g}=\arg \max \left[e\left(\gamma w_{1}^{g}(\rho=1)+(1-\gamma) w_{1}^{g}(\rho=0)\right)-c(e)\right]
$$

whereas under private ownership, the manager chooses $e^{p}$ so that

$$
e^{p}=\arg \max \left(e w_{1}^{p}-c(e)\right)=\arg \max \left(e \mu w_{0}^{p}-c(e)\right) .
$$

Clearly, $e^{g}>e^{p}$ when $\mu$ is close to zero, that is, when the product market is highly underdeveloped.

The analysis in this section thus highlights the potential trade-off in government ownership suggested in the Introduction. The exact nature of such a trade off determines the optimal ownership structure. The focus of the rest of my analysis is to understand how product market development influences this trade-off and hence the transformation of ownership form.

\section{Product Market Development and Optimal Ownership}

The optimal ownership form of the firm maximizes the social surplus that the firm generates. Let $S^{p}$ and $S^{g}$ denote the social surplus generated in equilibrium under private ownership and that under government ownership respectively. As argued in the previous section, government ownership is dominated by private ownership ex post. Therefore, government ownership will dominate private ownership only when government ownership significantly improves the $e x$ ante managerial incentives.

Lemma 3 Suppose that Assumption 1 holds. Government ownership dominates private ownership only if $e^{g}$ is sufficiently larger than $e^{p}$. 
The product market development influences the ranking between government ownership and private ownership through its impact on $e^{g}$ and $e^{p}$. It bears no effect to the social surplus generated after the government agency allocates the regulated product. As the next lemma shows, the product market development helps ex ante managerial effort under private ownership to catch up with that under private ownership provided that the following assumption holds:

Assumption $2 \frac{d^{3} c}{d e^{3}} \geq 0$.

Lemma 4 Suppose Assumption 1 and 2 hold. Then $\frac{\partial e^{p}}{\partial \mu}>\frac{\partial e^{g}}{\partial \mu}$ if $e^{g} \geq e^{p}$.

The intuition of Lemma 4, roughly speaking, is as follows. An improved product market increases the expected return on investment had the firm had to acquire a substitute from this market. This increment is larger under private ownership because the ex post managerial effort is higher under private ownership than under government ownership. Furthermore, because the manager has the full claim to the investment return, this larger increment under private ownership accrues entirely to the manager. In contrast, only a share of a smaller increase in the investment return accrues to the manager under government ownership. As a result, the value of the manager's outside option increases faster under private ownership than under government ownership. This implies that, ceteris paribus, the development of the product market tends to promote the ex ante managerial effort more intensively under private ownership.

Lemma 4 implies that the ex ante managerial effort under private ownership, which is smaller than the effort under government ownership when the product market is highly underdeveloped, will eventually catch up with the latter. It further implies that, once it catches up, the ex ante managerial effort under private ownership will not fall below that under government ownership again with further market development.

Lemma 5 Suppose Assumption 1 and 2 hold. Then there exists a unique solution to equation $e^{p}(\mu)=e^{g}(\mu)$.

Together Lemma 5 and Lemma 3 suggest that the social surplus under private ownership will eventually catch up with that under government ownership as well. Moreover, once it catches up, the social surplus under private ownership will not fall below that under government ownership again either, as I show in the next proposition.

Proposition 2 Suppose Assumption 1 and 2 hold. There exists $\mu^{s}$ such that private ownership is more efficient than government ownership if and only if $\mu>\mu^{s}$.

Proposition 2 reveals the existence of a unique turning point in the process of the market development, at which private ownership will begin to dominate government ownership once 
and for all. This point thus defines the socially optimal timing for privatization. However, will privatization actually take place at this particular point in equilibrium?

The way in which privatization takes place in equilibrium depends on, among other things, the bargaining between the government agency and buyers of the firm, i.e., the manager in this paper. This bargaining, if frictionless, could lead to privatization at the socially optimal timing. However, there are plenty reasons for such bargaining not to be frictionless, especially in the transition economy context, and an obvious form of friction is the manager's limited wealth. The rest of the paper will analyze the implication of the manager's wealth constraint on how privatization takes place in equilibrium. To prepare for that analysis, I trace out how the payoffs for both the government agency and the manager evolve with product market development under the two ownership forms.

A number of observations can be obtained. First, the government agency becomes in favor of private ownership prior to $\mu^{s}$ whereas the manager begins to prefer private ownership after $\mu^{s}$. To see this, notice that government ownership Pareto dominates private ownership when $\mu=0$. In addition, denote by $W^{p}(\mu)$ and $W^{g}(\mu)$ the manager's ex ante payoff under private ownership and that under government ownership respectively. Let $V^{p}(\mu)$ and $V^{g}(\mu)$ represent the corresponding terms for the government agency. Using the envelope theorem, one can show that $W^{g}(\mu) \geq W^{p}(\mu)$ if and only if $e^{g}(\mu) \geq e^{p}(\mu)$. Since private ownership dominates government ownership ex post, it must be true that $e^{g}\left(\mu^{s}\right)>e^{p}\left(\mu^{s}\right)$ (see Figure 7 in the proof of Lemma 3). This therefore implies that $W^{g}\left(\mu^{s}\right)>W^{p}\left(\mu^{s}\right)$, which in turn implies that $V^{g}\left(\mu^{s}\right)<V^{p}\left(\mu^{s}\right)$.

Second, further market development will not alter the manager's preference for private ownership once he becomes in favor of private ownership. Such irreversibility is a product of two effects. On the one hand, conditional on the investment being launched, the product market development enhances the manager's outside option, and hence his payoff, more intensely under private ownership than under government ownership. On the other hand, when the manager is in favor of private ownership, $e^{p}(\mu) \geq e^{g}(\mu)$ according to Lemma 4 . In other words, the likelihood of the investment being launched is higher under private ownership as well. Therefore, as described in the next lemma, the manager will be increasingly in favor of private ownership as the product market further develops.

Lemma 6 Suppose Assumption 1 and 2 hold. Then $W^{p}(\mu)-W^{g}(\mu)$ is increasing in $\mu$ for $\mu$ such that $W^{p}(\mu) \geq W^{g}(\mu)$.

Third, the rent-seeking government agency eventually becomes in favor of government ownership again when the product market becomes highly developed, provided that the market provides a close substitute to the intermediate product regulated by the government agency. The intuition is straightforward. When the product market grows mature, the government agency extracts little rent from the manager if the market provides a close substitute to the 
intermediate product regulated by the government agency. Government ownership, on the other hand, allows it to continue to share the investment return. To simplify the discussion, I assume for the rest of the paper that the product market offers a perfect substitute for the government-regulated product.

The next proposition summarizes these observations, which are also illustrated in Figure 1.

Proposition 3 Suppose that Assumption 1 and 2 hold. There exists $\mu_{1}^{g}, \mu^{m}$, and $\mu_{2}^{g}$ such that $\mu_{1}^{g}>\mu^{s}>\mu^{m}>\mu_{2}^{g}$ where:

a) the manager weakly prefers government ownership to private ownership if and only if $\mu \leq \mu^{m} ;$ and

b) the government agency weakly prefers government ownership to private ownership if $\mu \leq \mu_{1}^{g}$ or $\mu \geq \mu_{2}^{g}$.

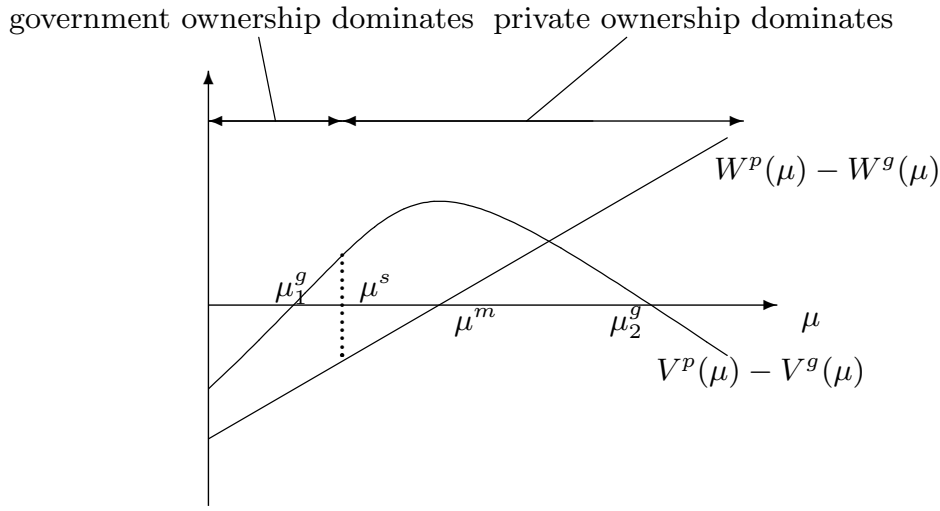

Figure 1: Payoff Differences under Private and Government Ownership

Notice that, different from what is claimed in Proposition 3, in Figure 1 the government agency prefers government ownership to private ownership if and only if $\mu \leq \mu_{1}^{g}$ or $\mu \geq \mu_{2}^{g}$. In other words, once the product market matures to such a level that the government agency turns to favor government ownership again, further market development will no longer change its preference. This particular pattern holds under the following assumption, which is satisfied for some fairly general cost function $c(e)$ (such as a quadratic one, for example).

Assumption $3 V^{g}(t)-V^{p}(t)$ is increasing in $t$ for all $t \geq t^{s}$ such that $V^{g}(t)>V^{p}(t)$. 


\section{The Equilibrium Privatization}

I am now ready to analyze how ownership transformation will actually take place in equilibrium. I begin my analysis with full privatization. The possibility of partial privatization will be incorporated in section 6 .

\subsection{The extended model}

To analyze how privatization takes place in equilibrium, I extend the baseline model as follows. Time is continuous and has an infinite horizon. Each point of time is a period in the baseline model. The government agency's type, $\theta$ is distributed identically and independently across these periods. The manager is assumed to be indispensable for the firm. Therefore, in each period, the government agency has to deal with the same manager. To make my analysis tractable, I assume that both the manager's strategy and that of the government agency within a period are history independent. The government agency and the manager share the same discount rate $r$. The product market becomes increasingly developed over time; a process that is assumed to be exogenous and is characterized by $\mu(t)$ where $\mu(0)=0$ and $\frac{d \mu}{d t}>0$ for $\mu<1$.

At each point in time, an ownership form is chosen for the investment taking place at the point. As before, I assume that the ownership form cannot be altered until the investment is completed, that is, until the next point in time. The change in ownership form is accompanied by a transfer payment made either from the manager to the government agency or vice versa.

Using the fact that the social surplus under the two ownership forms cross only once (see Proposition 2), I can show that ownership transformation takes place at most once:

Lemma 7 Suppose Assumption 1 and 2 holds. Then ownership transformation, if ever takes place, takes place only once.

Recall that government ownership Pareto dominates private ownership when $\mu=0$. I assume that the firm indeed begins with government ownership at $t=0$. Lemma 7 thus implies that ownership transformation, if any, takes the form of privatization, and furthermore privatization is irreversible once it does take place.

The government agency has all the bargaining power during privatization. In particular, at any point of time, the government agency decides whether to privatize the firm, and if so, at what transfer payment, or price, denoted by $s^{p}(t)$. When $s^{p}(t)$ is positive, the amount is made from the manager to the government agency, and is negative otherwise. The manager can either accepts or rejects the government agency's offer. If the offer is rejected, government ownership is maintained. And at the next point in time, the government agency has to decide again whether to privatize and at what transfer payment. 
The bargaining over the ownership rights is subject to the wealth constraint faced by the manager. I assume the price affordable by the manager at any point is bounded above by $s^{*} \geq 0$. On the other hand, the government agency is not wealth constrained. Hence, $s^{p}(t) \in\left(-\infty, s^{*}\right] \cdot{ }^{10}$

\subsection{The equilibrium conditions}

Define $P D W^{p}(t)$ (and $P D V^{p}(t)$ ) as the long-term payoff for the manager (and for the government agency respectively) when the firm is privately owned at $t$. In addition, denote by $P D W^{g}\left(t ; t^{\prime}\right)$ (and $P D V^{g}\left(t ; t^{\prime}\right)$ ) as the long-term payoff for the manager (and for the government agency respectively) at $t$ while privatization is to take place at $t^{\prime}>t$.

For privatization to be feasible at $t$, both the government agency and the manager must find it more desirable than never privatizing at all:

$$
\begin{aligned}
P D W^{p}(t)-s^{p}(t) & \geq P D W^{g}(t ; \infty) & & \text { for } t \in[0, \infty), \text { and } \\
P D V^{p}(t)+s^{p}(t) & \geq P D V^{g}(t ; \infty) & & \text { for } t \in[0, \infty) .
\end{aligned}
$$

In addition, when privatization takes place at $t$, the manager must also be able to afford the payment $s^{p}(t)$, i.e.,

$$
s^{p}(t) \leq s^{*}
$$

Together, condition (2) and (3) imply that privatization will take place only if, from a long-term perspective, private ownership Pareto dominates government ownership. Define $t_{0}$ as a point such that:

$$
P D W^{p}\left(t_{0}\right)+P D V^{p}\left(t_{0}\right)=P D W^{g}\left(t_{0} ; \infty\right)+P D V^{g}\left(t_{0} ; \infty\right)
$$

As I prove in the next lemma, $t_{0}$ is the "starting point" that private ownership Pareto dominates government ownership in the long run.

Lemma 8 There exists a price $s^{p}(t)$ that is affordable to the manager and satisfies the participation constraints (2) and (3) if and only if $t \in\left[t_{0}, \infty\right)$ and

$$
s^{*} \geq P D V^{g}(t ; \infty)-P D V^{p}(t) .
$$

\footnotetext{
${ }^{10}$ The wealth constraint in this model is assumed to be time-invariant. More realistically, the manager may accumulate wealth over time. However, endogenizing the wealth accumulation tremendously complicates the analysis without adding significant insights. Alternatively, one may imagine that at each point in time, the manager exogenously receive a small budget that allows him to add to his stock of wealth after paying the fee to the government agency (consequently, there is no wealth constraint in acquiring the intermediate product). The wealth constraint $s^{*}$ can then be modelled as an exogenous function of time. In this case, the time-invariant assumption can be regarded as an approximation for the product market development being much faster than the manager's wealth accumulation.
} 
Denote by $t^{e}$ the timing at which privatization takes place in equilibrium. To privatize the firm at $t^{e}$, the government agency needs to make sure that the manager will not reject $s^{p}\left(t^{e}\right)$, the price it offers and delay the privatization till future. That is,

$$
P D W^{p}\left(t^{e}\right)-s^{p}\left(t^{e}\right) \geq P D W^{g}\left(t^{e} ; t^{\prime}\right), \quad \text { for any } t^{\prime}>t^{e}
$$

Notice, however, that the value of $P D W^{g}\left(t^{e}, t^{\prime}\right)$ depends on $s^{p}\left(t^{\prime}\right)$, the price the government agency would offer at $t^{\prime}$ if the firm had not been privatized by that time. Since the government agency cannot pre-commit to a price at $t^{\prime}, s^{p}\left(t^{\prime}\right)$ must also satisfy an incentive compatibility constraint similar to $(6)$.

Denote by $\check{s}^{p}(t)$ an incentive compatible price that satisfies condition (6) (and hence condition (2) as well) if privatization were to take place at $t$. At any point $t$, the government agency, attempting to exercise its bargaining power, will choose the highest $\check{s}^{p}(t)$. Define $\tilde{s}^{p}(t)$ as the resulting maximum for $t$. $\tilde{s}^{p}(t)$ is the subgame perfect price if privatization is to take place at $t$.

In equilibrium, the government agency must neither want to privatize later than $t^{e}$ :

$$
P D V^{p}\left(t^{e}\right)+\tilde{s}^{p}\left(t^{e}\right) \geq P D V^{g}\left(t^{e} ; t^{\prime}\right)
$$

for any $t^{\prime}>t^{e}$, nor earlier than $t^{e}$ :

$$
P D V^{p}\left(t^{\prime \prime}\right)+\tilde{s}^{p}\left(t^{\prime \prime}\right) \geq P D V^{g}\left(t^{\prime \prime} ; t^{e}\right),
$$

for any $t^{\prime \prime}<t^{e}$.

A privatization equilibrium is therefore defined as a stream of subgame perfect prices $\tilde{s}^{p}(t)$ for $t \in\left[t_{0}, \infty\right)$ that satisfies condition (3) and (4), and a subgame perfect equilibrium timing of privatization $t^{e}$ that satisfies condition (7) and (8).

\subsection{Type I and type II wealth constraint}

In two ways the manager's limited wealth may affect how privatization takes place. On the one hand, the manager may not have enough to compensate for the government agency for the ownership rights it will relinquish, in which case privatization will not be feasible.

$$
P D V^{g}(t ; \infty)-P D V^{p}(t)>s^{*} .
$$

I refer to this situation as the wealth constraint being binding in type I at $t$. On the other hand, the wealth constraint may also imply that the government agency cannot take full advantage of its bargaining power, and as a result the willingness of the manager to pay for 
the ownership rights is not exhausted.

$$
P D W^{p}(t)-P D W^{g}(t ; \infty)>s^{*}
$$

I refer to this second situation as the wealth constraint being binding in type II at $t$. When the wealth constraint is binding in type II but not in type I at $t$, privatization is feasible at $t$ but the government agency is not able to extract all the gains from privatization.

The next lemma summarizes a number of useful observations with regard to these two types of wealth constraints, which are further characterized in Figure 2.

Lemma 9 Suppose Assumption 1 and 2 hold. Then for $t \geq t_{0}$, the wealth constraint must binding in

a) type II at $t$ if it is binding in type I at $t$;

b) type II for $t^{\prime}>t$ if it is binding in type II at $t$; and

c) type I for $t^{\prime}>t$ when it is binding in type I at $t \geq t^{s}$, provided that Assumption 3 holds in addition.

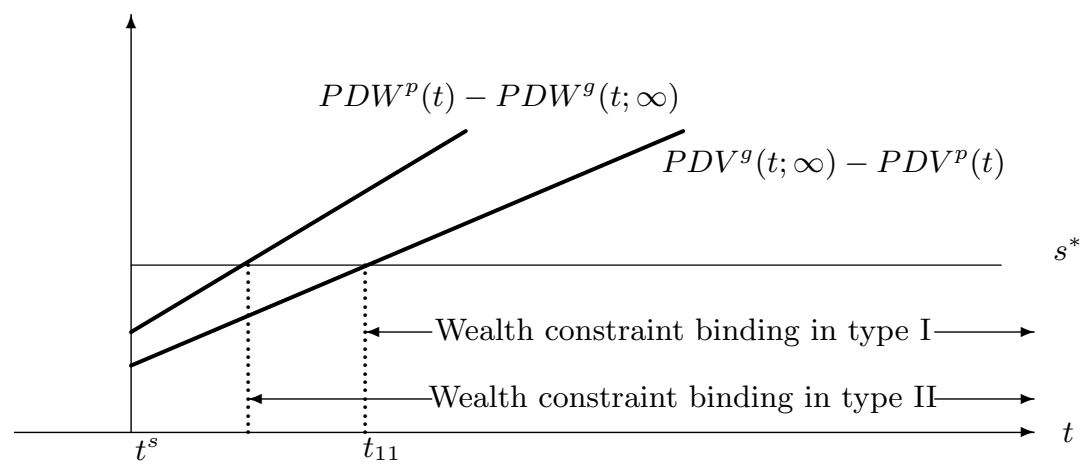

Figure 2: Type I and II binding wealth constraint

In Figure 2, $P D W^{p}(t)-P D W^{g}(t ; \infty)$ is increasing in $t$ for $t \geq t^{s}$. Such monotonicity is derived using the fact that $W^{p}\left(t^{s}\right)<W^{g}\left(t^{s}\right)$ and Lemma 6 . The same pattern holds for $P D V^{g}(t ; \infty)-P D V^{p}(t)$ as well, and it results from the fact that $V^{g}\left(t^{s}\right)>V^{p}\left(t^{s}\right)$ and Assumption 3. $P D W^{p}(t)-P D W^{g}(t ; \infty)>P D V^{g}(t ; \infty)-P D V^{p}(t)$ for $t \geq t^{s}$ as $t^{s}>t_{0}$. This figure demonstrates a case where there exists a point beyond which privatization is no longer feasible. I denote such an "end point" by $t_{11}$. Naturally, $t_{11}$ satisfies the following condition.

$$
P D V^{g}\left(t_{11} ; \infty\right)-P D V^{p}\left(t_{11}\right)=s^{*}
$$


and privatization can take place at $t$ only if $t \in\left[t_{0}, t_{11}\right]$.

The reason for introducing the type II constraint can be seen by considering the following case. Suppose that the wealth constraint is never binding in type II for $t \geq t^{s}$. According to part (a) of Lemma 9, this implies that the wealth constraint is never binding in type I for $t \geq t^{s}$ either. In this case, privatization will take place at the optimal timing $t^{s}$ in equilibrium and the government agency will grab the entire gains from privatization. This is because at any point after $t^{s}$, it would always be optimal for the government agency to set the privatization price $s^{p}(t)$ to exhaust its bargaining power, i.e., $s^{p}(t)=P D W^{p}(t)-P D W^{g}(t: \infty)$, should privatization have not taken place by then. As a result, the manager would never be able to capture any gains from privatization after $t^{s}$ and will therefore have no incentive to postpone privatization, but to accept the government agency's privatization proposal at $t^{s}$.

Proposition 4 Suppose that Assumption 1 and 2 hold. Suppose in addition that the wealth constraint is never binding in type II for all $t \geq t^{s}$. Then

a) the equilibrium timing of privatization is efficient: $t^{e}=t^{s}$; and

b) the government agency receives all the gains from privatization.

The rest of this section focuses on scenarios where the wealth constraint is binding (either in type I or in type II) for some $t \geq t^{s}$. Following part (a) of Lemma 9, I divide the analysis into two subsections. The next subsection deals with the case when the wealth constraint is not binding in type I at $t^{s}$, but binding in type II at some $t \geq t^{s}$. In this case, privatization is feasible at $t^{s}$, and yet the government agency would become unable to extract all the gains from privatization, if privatization were to take place after $t$. Then I consider the case where the wealth constraint is binding in type $\mathrm{I}$, and hence privatization is not feasible, at $t^{s}$.

My analysis is designed to address the following two questions that have been studied extensively in the literature: Will privatization improve firm performance? Will the firm be underpriced during privatization, and why?

\subsection{Underpricing and wealth constraint off-equilibrium}

Consider the first case first. In this case, privatization is feasible at $t^{s}$, but the government agency is unable to extract all the gains from privatization at some $t \geq t^{s}$ had privatization failed to take place by that time. Notice this case includes the possibility for the wealth constraint to be not binding in type II at $t^{s}$, which would imply that the firm can be priced to exhaust the manager's willingness to pay, if the firm is privatized at the social optimal timing. However, will the firm be privatized at the social optimal timing? Will the firm be priced to exhaust the manager's willingness to pay?

When the wealth constraint becomes binding in type II, some gains from privatization accrue to the manager. Anticipating this situation to arise in the future, the manager may 
try to postpone privatization. Such an attempt will then force the government agency to reduce the price in order to "reward" the manager for agreeing to privatization today. This is the intuition that drives the analysis for this particular case.

To begin, recall that a subgame perfect price $\tilde{s}^{p}(t)$ must satisfy the incentive compatibility constraint (6) if privatization were to take place $t$. Combining (6) and the fact that the government agency has all the bargaining power, I can show that a subgame perfect transfer payment $\tilde{s}^{p}(t)$ satisfies the following differential equation:

$$
\frac{d \tilde{s}^{p}(t)}{d t}=r \tilde{s}^{p}(t)-\left(W^{p}(t)-W^{g}(t)\right) \cdot{ }^{11}
$$

for $t \in\left[t_{0}, t_{11}\right]$.

When postponing privatization, the manager loses the marginal gain of privatization $W^{p}(t)-W^{g}(t)$ but gains as he is able to discount the current privatization price $r \tilde{s}^{p}(t)$. Equation (10) states that, in order for the manager to accept privatization at $t$, the privatization price must change from point $t$ in such away that it offsets the manager's incentive to postpone privatization.

Apparently, had the firm not been privatized by $t_{11}$, the government agency would price the firm at $s^{*}$, since further delay by the manager is no longer feasible. However, even prior to $t_{11}$, the government agency may choose to price at $s^{*}$ as well. Such a scenario arises when the manager does not find it in his own interest to delay privatization, even if the government agency prices the firm at $s^{*}$ from that point on. I refer to this point as $t_{12}$. According to condition (10), $t_{12}$ is given by:

$$
W^{p}\left(t_{12}\right)-W^{g}\left(t_{12}\right)=r s^{*}
$$

Following the fact that $W^{p}\left(t^{s}\right)<W^{g}\left(t^{s}\right)$ (see Proposition 3) and part (b) of Lemma 9, I have $t_{12}>t^{s}$. Combining these observations together, I can conclude that there exists a point, denoted by $t_{1}$, from that on the government agency would price the firm at what the manager could afford, had the firm not been privatized. That is, $t_{1}=\min \left\{t_{11}, t_{12}\right\}$, and

$$
\tilde{s}^{p}\left(t_{1}\right)=s^{*}
$$

Because privatization is feasible at $t^{s}$ in the present case and because $W^{p}(t)-W^{g}(t)>0$ only if $t>t^{s}$, I have $t_{1}>t^{s}$ in this present case. Furthermore, since $W^{p}(t)-W^{g}(t)$ is increasing

\footnotetext{
${ }^{11}$ This equation is derived as follows. First, I can show that condition (6) holds for $t \in\left[t_{0}, t_{11}\right)$ only if $\frac{d \tilde{s}^{p}(t)}{d t} \geq r \tilde{s}^{p}(t)-\left(W^{p}(t)-W^{g}(t)\right)$. Then using the fact that the government agency has all the bargaining power, I set $\frac{d \tilde{s}^{p}(t)}{d t}=r \tilde{s}^{p}(t)-\left(W^{p}(t)-W^{g}(t)\right)$.
} 
in $t$ when $W^{p}(t)>W^{g}(t)$ (see Lemma 6 ), $t_{1}$ also has the property that

$$
W^{p}\left(t_{1}\right)-W^{g}\left(t_{1}\right) \leq r s^{*}
$$

Using the transversality condition (11), I can solve the differential equation (10) and obtain the entire stream of the subgame perfect prices $\tilde{s}^{p}(t)$ for $t \in\left[t_{0}, t_{1}\right]$ :

$$
\tilde{s}^{p}(t)=\int_{t}^{t_{1}} e^{-r(z-t)}\left(W^{p}(z)-W^{g}(z)\right) d z+e^{-r\left(t_{1}-t\right)} s^{*} .
$$

Substituting (13) into (10), and using Lemma 6 and condition (12), I can show that

$$
\frac{d \tilde{s}^{p}(t)}{d t}>0
$$

for $t \in\left(t_{0}, t_{1}\right)$. From the point of view of backward induction, such monotonicity demonstrates a downward pressure on the transfer payment. That is, if the government agency wants to privatize earlier, it must lower the current privatization price as compared to the privatization price in the future.

This downward pressure implies that the wealth constraint, condition (4), must not be binding for all $t \in\left[t_{0}, t_{1}\right)$. Furthermore, since $P D W^{p}(t)-P D W^{g}(t ; \infty)>P D W^{p}(t)-$ $P D W^{g}\left(t, t^{\prime}\right)$ for any $t$ and $t^{\prime}>t$, the participation constraint for the manager, condition (2), must not be binding either for all $t \in\left[t_{0}, t_{1}\right)$. Finally, I can show that $\tilde{s}^{p}(t)$ satisfies the participation constraint (3) for all $t \in\left[t^{s}, t_{1}\right]$ as well. ${ }^{12}$ These observations combined together imply that $\tilde{s}^{p}(t)$ is both feasible and incentive compatible for the manager as long as the firm is not privatized prematurely, i.e., as long as $t^{e} \geq t^{s}$.

Will the firm be privatized prematurely in this case? The answer is negative. To see this, notice that in order to privatization to take place at $t^{e}$, condition (7) must be satisfied. With some manipulation, I can reduce this condition to:

$$
V^{g}\left(t^{e}\right)-V^{p}\left(t^{e}\right)-r \tilde{s}\left(t^{e}\right)+\frac{d \tilde{s}\left(t^{e}\right)}{d t^{e}} \leq 0
$$

\footnotetext{
${ }^{12}$ Differentiating $P D V^{g}(t ; \infty)-P D V^{p}(t)$ with respect to $t$, I have:

$$
\frac{\partial\left(P D V^{g}(t ; \infty)-P D V^{p}(t)\right)}{\partial t}=r\left(P D V^{g}(t ; \infty)-P D V^{p}(t)\right)-\left(V^{g}(t)-V^{p}(t)\right) .
$$

Comparing (14) with (10) and given the fact $S^{p}(t)-S^{g}(t)>0$ for $t>t^{s}$, I have the following single-crossing property:

$$
\frac{\partial\left(P D V^{g}(t ; \infty)-P D V^{p}(t)\right)}{\partial t}>\frac{d \tilde{s}^{p}(t)}{d t}
$$

for $t \in\left[t^{s}, t_{1}\right]$ such that $P D V^{g}(t ; \infty)-P D V^{p}(t)=\tilde{s}^{p}(t)$. This single-crossing property then implies, for any $t \in\left[t^{s}, t_{1}\right]$, the incentive compatible transfer payment must be more than enough to compensate the government agency for the ownership rights. That is, condition (3) is satisfied for $t \in\left[t^{s}, t_{1}\right]$.
} 
Substituting condition (10) into this condition, I have $S^{p}\left(t^{e}\right) \geq S^{g}\left(t^{e}\right)$, hence $t^{e} \geq t^{s}$. That is, the firm will never be privatized prior to the social optimal timing in the present case.

Will privatization take place after $t^{s}$ in equilibrium? The answer is no as well. Given that none of the conditions (2), (3), and (4) is binding for $t \in\left[t^{s}, t_{1}\right)$, in order for privatization to take place at $t^{e} \in\left(t^{s}, t_{1}\right)$, condition (8) must hold. As in the case of condition (7), this condition can be reduced as

$$
V^{g}\left(t^{e}\right)-V^{p}\left(t^{e}\right)-r \tilde{s}\left(t^{e}\right)+\frac{d \tilde{s}\left(t^{e}\right)}{d t^{e}} \geq 0
$$

Combining (15) and (16) together, I have:

$$
V^{g}\left(t^{e}\right)-V^{p}\left(t^{e}\right)-r \tilde{s}\left(t^{e}\right)+\frac{d \tilde{s}\left(t^{e}\right)}{d t^{e}}=0
$$

Substituting condition (17) into condition (10), I have $S^{p}\left(t^{e}\right)=S^{g}\left(t^{e}\right)$, which contradicts to the assumption that $t^{e}>t^{s}$.

Proposition 5 Suppose Assumption 1, 2, and 3 hold. Suppose in addition that the wealth constraint is not binding in type $I$ at $t^{s}$, but is binding in type II for some $t \geq t^{s}$. Then

a) privatization takes place in equilibrium at the socially optimal timing, i.e., $t^{e}=t^{s}$; and

b) the firm is underpriced during privatization in the sense that $\tilde{s}^{p}\left(t^{e}\right)<\min \left\{s^{*}, P D W^{p}\left(t^{e}\right)-\right.$ $\left.P D W^{g}\left(t^{e} ; \infty\right)\right\}$.

To illustrate Proposition 5, I present Figure 3, which by itself represents two scenarios: one in which $t_{1}=t_{12}$ (the upper panel) and the other scenario where $t_{1}=t_{11}$ (the lower panel). Notice that in both scenarios, the wealth constraint is not binding either in type I or in type II at $t^{s}$. The upper panel further suggests the possibility that the wealth constraint is never binding in type I. It demonstrates that the government agency would always set the privatization price $\tilde{s}^{p}(t)=s^{*}$ from $t_{12}$. Prior to $t_{12}$, however, the government agency has to lower the privatization price in order to encourage the manager to agree to privatize earlier. In equilibrium, privatization takes place at $t^{s}$ at a price that does not exhaust either the manager's ability to pay $s^{*}$ or his willingness to pay $P D W^{p}\left(t^{s}\right)-P D W^{g}\left(t^{s} ; \infty\right)$. The lower panel tells a similar story.

Proposition 5 thus implies that the wealth constraint, when it is binding only along the offequilibrium path (i.e, for $t>t^{s}$ ), has a redistributive effect but no efficiency effect. That is, the firm will be privatized at $t^{s}$ and the firm will be underpriced during privatization. One natural question is whether the underpricing phenomenon, thus described, is robust. In particular, to what extent does this result depend on the fact that in this model the firm is privatized to a single buyer? It turns out that the single buyer assumption is less restrictive than it appears. 

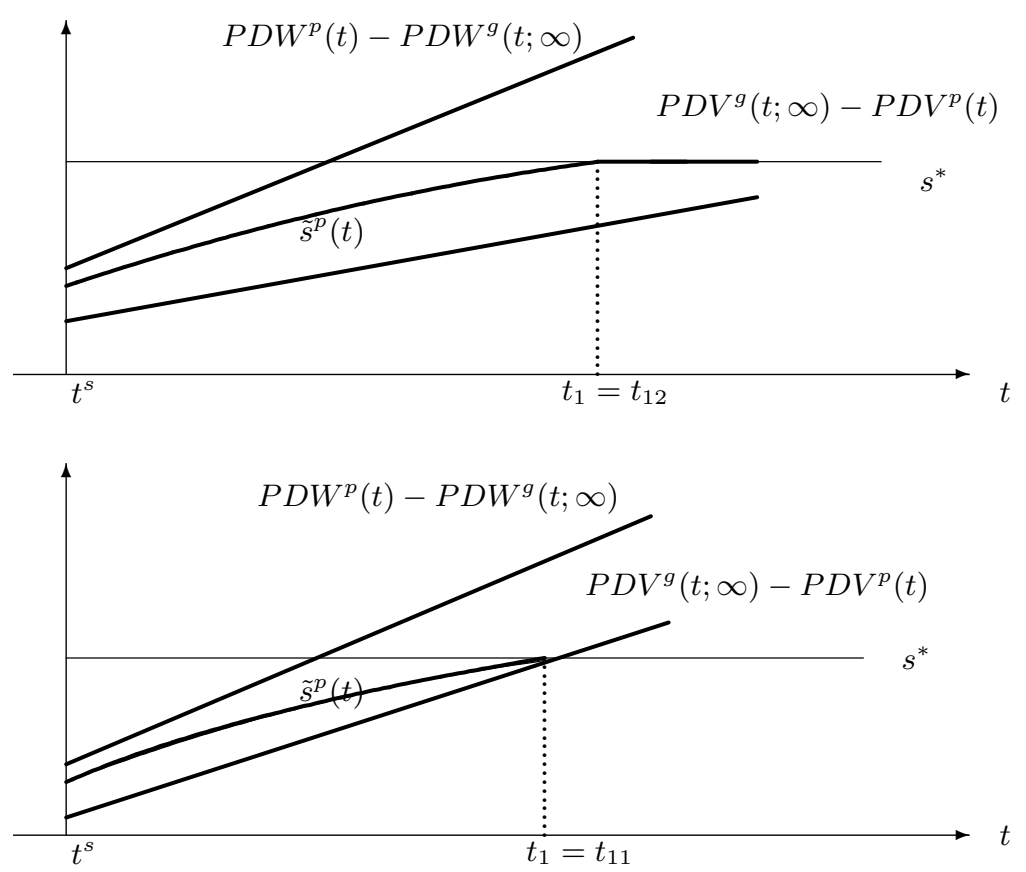

Figure 3: Underpricing when wealth constraint is binding off-equilibrium

In fact, one can show that there can be underpricing in equilibrium, even when the firm can be privatized to anyone of finitely many insiders that are all wealth constrained. Nonetheless, the underpricing phenomenon will not emerge if the government agency could commit to a strategy of "privatizing now or never". Yet it is not clear whether such commitment can be credible. And aside from the issue of credibility, such a strategy may force privatization to take place prematurely, a subject I discuss next. ${ }^{13}$

\subsection{Does privatization improve firm performance?}

Together, Proposition 4 and 5 suggest that privatization will take place at the social optimal point as long as privatization is feasible at that point. Next, consider the case where privatization is not feasible at the social optimal point; that is, the wealth constraint is binding in type I at $t^{s}$. To relieve this constraint, the government agency may either postpone the privatization or privatize prematurely. Following part (c) of Lemma 9, the wealth constraint is binding in type I for all $t>t^{s}$, implying that $t_{11}<t^{s}$ in this case. Accordingly, privatization

\footnotetext{
${ }^{13}$ One can show that, when the wealth constraint is binding in type II at $t^{s}$, the strategy of "privatizing now or never" will give rise the equilibrium timing $t^{e}$ such that $V^{g}\left(t^{e}\right)-V^{p}\left(t^{e}\right)=r s^{*}$.
} 
would be feasible only if the government agency privatizes the firm prematurely.

Proposition 6 Suppose that Assumption 1, 2, and 3 hold. Suppose in addition that the wealth constraint is binding in type $I$ at $t^{s}$. Then privatization, if it ever takes place, takes place at $t_{11}$.

Privatization will not take place prior to $t_{11}$ because otherwise, both condition (10) and (15) must be satisfied at $t^{e}$, which gives $S^{p}\left(t^{e}\right) \geq S^{g}\left(t^{e}\right)$, implying that $t^{e} \geq t^{s}$. This contradicts to the fact that privatization is not feasible for $t \geq t^{s}$ in this case. Proposition 6 suggests that, when the manager's limited wealth prevents privatization from taking place at the optimal timing, privatization will not take place until the market development reaches a point beyond which privatization is no longer feasible.

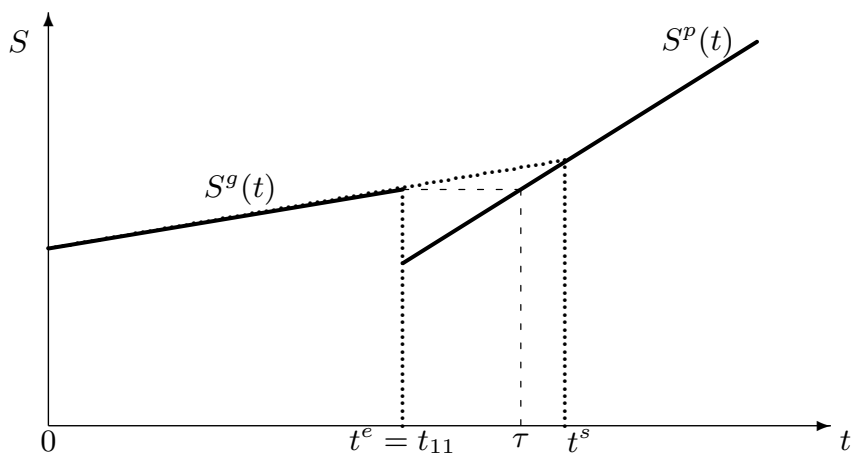

Figure 4: Social surplus and premature privatization in equilibrium

Figure 4 illustrates how the social surplus generated by the firm evolves over time in this case. As the product market develops, the social surplus under government ownership increases; at $t_{11}<t^{s}$, privatization takes place, causing the social surplus to dip in the short run. In the long run, however, the social surplus under private ownership surpasses that of government ownership. In other words, the firm exhibits $J$-curve-like post-privatization performance.

This observation has a number of important empirical and policy implications. First, even though private ownership dominates government ownership in the long run, it is possible to observe privatized firms to perform less efficiently than government-owned firms immediately after privatization. How long a period of time over which a panel data is gathered is likely to influence the conclusion of the empirical study concerning the relative performances of privatized firms.

Furthermore, it may be necessary to analyze not only the levels, but perhaps more importantly, the trends of performance both before and after privatization in order to evaluate 
whether privatization improves firm performance. For example, as Figure 4 indicates, the performance under private ownership at $\tau$ catches up with the level of performance under government ownership at $t_{11}$. However, the performance of government ownership at this particular point would continue to dominate that of private ownership, had the firm not been privatized. Since the potential performance under government ownership after privatization is not observable, in order to reach a correct conclusion of whether privatization improves firm performance at $\tau$, it is important to estimate the projected trend of firm performance under government ownership after $t^{s}$. And to obtain a good estimate of such a trend, one should use long-term performance data both prior to and after privatization. ${ }^{14}$

There has been mixed empirical evidence on the performance effect of privatization , especially in the context of transition economies (Bevan, Estrin, and Schaffer 1999 and Svejnar 2002). And the existing literature have attributed the disappointing record of privatization to the lack of in-depth institutional reforms (Svejnar 2002, Zinnes, Eilat, and Sachs 2001) to safeguard problems such as asset stripping (Aghion, Blanchard and Burgess 1994), insider entrenchment (Aghion and Blanchard 1998), and soft budget budget constraints (Debande and Friebel 1997). This paper offers a complementary interpretation. According to my analysis, privatization fails to improve the firm performance in the short run because, when privatization takes place, the product market has not matured to the state of $\mu^{s}$. In this regard, my analysis echoes the argument for in-depth institutional reforms. Meanwhile, my analysis also suggests that the worsening performance could arise as a transitory phenomenon in equilibrium. In particular, the rent-seeking minded government agency deliberately allows privatization to take place prior to $t^{s}$ while anticipating the product market to grow mature in the future. And exactly because the product market continues to evolve after privatization, the deterioration in performance is only transitory. In other words, even with in-depth institutional reform in place, it will still be possible for privatization to take place prematurely, leading to the performance of a firm to deteriorate in the short run.

Finally, this observation highlights a dynamic cost of government ownership that is not present in the static analysis. Recall that there is a trade-off between government ownership and private ownership in the static model: government ownership helps create an ex ante commitment effect while rendering the firm less efficient ex post. In a dynamic setting, government ownership also allows the government agency to reap gains from privatization. In the presence of the manager' wealth constraint, such an attempt by the rent seeking government agency leads to an inefficient privatization process.

\footnotetext{
${ }^{14}$ Long-term performance data prior to privatization helps reveal underlying characteristics of the firm under government ownership, whereas long-term performance data after privatization helps tell how the external environment, such as the product market for example, evolves after privatization takes place. Notice that because the product market development affects all firms, cross-section data is unlikely to pick up such an effect.
} 


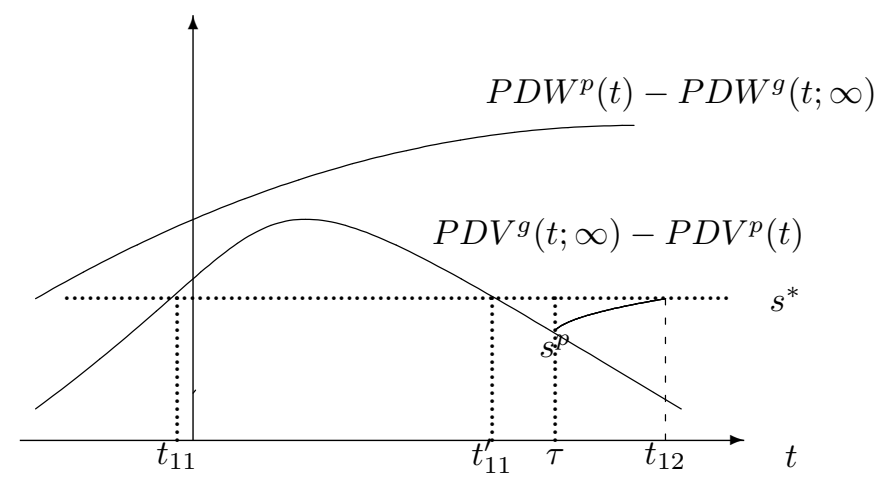

Figure 5: Premature privatization without Assumption 3

The possibility that the firm is privatized prematurely has to with Assumption 3, which guarantees the monotonicity of $P D V^{g}(t ; \infty)-P D V^{p}(t)$ for $t \geq t^{s}$ (see the proof of Lemma $9)$. A natural question is how restrictive this assumption is, or more precisely, what happens if $P D V^{g}(t ; \infty)-P D V^{p}(t)$ fails to observe the monotonicity for $t \geq t^{s}$.

Figure 5 illustrates a situation where $P D V^{g}(t ; \infty)-P D V^{p}(t)$ is not monotonic after $t^{s}$ and privatization becomes feasible again at $t_{11}^{\prime}>t^{s}$. As Figure 5 shows, had privatization not taken place at $t_{11}^{\prime}$, it would then take place at $\tau$ at the price $s^{p}$. The curve connecting $s^{p}$ and $s^{*}$ represents the stream of subgame perfect privatization prices the government agency would offer after $\tau$. Naturally, as long as $t_{11}^{\prime}$ is sufficiently large, privatization at $t_{11}$ instead can make both the government agency and the manager better off. In this sense, the results presented in Proposition 6 are qualitatively robust. In fact, using the same intuition that I will develop in the next section, I can show that the possibility to privatize the firm at $t_{11}^{\prime}$ could actually induce the government agency and the manager to agree to privatize the firm even prior to $t_{11}$.

\section{Full Privatization v.s. Partial Privatization}

The foregoing analysis focuses on full privatization under the manager's wealth constraint. While financial underdevelopment in transition economies (Berglof and Bolton 2003) may prevent the manager from raising money from outsiders, some financial arrangement can be made between the government agency and the manager to relieve the constraint. One of such arrangements is partial privatization. Indeed, partial privatization has been viewed as a "second best" instrument when buyers are wealth constrained. My analysis in this section examines this proposition. The key insight I will derive is that partial privatization may be used by the government agency as an off-equilibrium threat point to enhance its bargaining 
power during full privatization, and that such an increase in bargaining power has both redistributive as well as efficiency implications when the manager are wealth constrained.

To do so, I extend the dynamic model as follows. At any point in time, the government agency can choose either full privatization or partial privatization. Denote by $\beta, \beta \in\{0, \lambda\}$, the choice between full privatization $(\beta=0)$ and partial privatization $(\beta=\lambda)$. The government agency retains $\lambda$ share of the investment return but relinquishes its control rights after partial privatization. I refer to a firm as fully private owned after it is fully privatized, and one as partially private owned vice versa. I use $\beta=0$ to index variables for a fully private owned firm and $\beta=\lambda$ to index those for a partially private owned firm. For example, $P D V^{p}(t, \lambda)$ will be the long-term payoff for the government agency at $t$ when the firm is partially private owned at that time. Similarly, $P D W^{g}\left(t ; t^{\prime}, 0\right)$ will be the long-term payoff for the manager at $t$ if the firm is under government ownership at $t$ but is to become fully private owned at $t^{\prime}$. When it is not indexed by $\beta$, a variable either corresponds to the previous analysis where partial privatization is not considered as an option, or is independent of whether the firm is fully or partially privatized.

To simplify the discussion, I make the following assumption:

Assumption 4 a) $c(e)=c e^{2}, c>0$;

b) $w_{0}^{p}(\lambda)\left[R_{1}\left(a^{p}(\lambda)\right)-c\left(a^{p}(\lambda)\right)-w_{0}^{p}(\lambda)\right]>w_{0}^{p}(0)\left[R_{1}\left(a^{p}(0)\right)-c\left(a^{p}(0)\right)-w_{0}^{p}(0)\right]$.

This assumption guarantees that the government agency always prefers a partially privatized owned firm to one that is fully privatized owned. This further implies that partial privatization remains feasible beyond the "end point" for full privatization. In addition, this assumption implies that the difference in the government agency's payoffs between a partially privatized firm and a fully-privatized one is increasing over time. The next lemma summarizes these implications.

Lemma 10 Suppose Assumption 4 holds. Then

a) $V^{p}(t, \lambda)>V^{p}(t, 0)$ for any $t$;

b) $t_{11}(\lambda)>t_{11}(0)$; and

c) $V^{p}(t, \lambda)-V^{p}(t, 0)$ is increasing in $t$.

Finally, note that Assumption 3 and 2 hold when the cost function $c(e)$ is quadratic.

\subsection{Partial privatization as a bargaining chip}

To show how the possibility of partial privatization helps strengthens the bargaining position of the government agency, I divide my ensuing analysis into two scenarios. In the first, 
benchmark scenario, the government agency always prefers partial privatization to full privatization. In the second one, which is the scenario my analysis will focus on, the government agency finds itself better off to fully privatize the firm at some point.

I begin with the benchmark scenario. The notion that "the government agency always prefers partial privatization to full privatization" will be precisely defined later, but loosely speaking, it means the following: At any $t$, if the government agency were to fully privatize the firm at that point, there exists a later point in time, $\tau \geq t$, at which the government agency is better off to partially privatize the firm at $\tau$ than to fully privatize the firm at $t$. I restrict my attention to $\tau \geq t$ to maintain subgame perfection.

Denote by $t^{s}(\lambda)$ the point where

$$
S^{p}\left(t^{s}(\lambda), \lambda\right)=S^{g}\left(t^{s}(\lambda)\right)
$$

$t^{s}(\lambda)$ is therefore the "second best" timing for partially privatization. Naturally, $t^{s}(\lambda)>t^{s}$, for full privatization yields a larger amount of social surplus than partial privatization for all t. Applying my previous analysis (see Proposition 4 and 5), I can conclude that the firm will be partially privatized at $t^{s}(\lambda)$ in this scenario, provided that the wealth constraint is not binding in type I for partial privatization at $t^{s}(\lambda)$, a condition I assume to hold in order to simplify the discussion.

Assumption $5 s^{*} \geq P D V^{g}\left(t^{s}(\lambda) ; \infty\right)-P D V^{p}\left(t^{s}(\lambda), \lambda\right)$.

I now turn to the second scenario. To define this scenario precisely, notice first that partial privatization remains implementable after full privatization is no longer feasible (i.e., $\left.t_{11}(\lambda)>t_{11}(0)\right)$. In other words, ownership transformation would eventually take the form of partial privatization. This implies that if the government agency implements full privatization in a subgame perfect equilibrium, the manager must be better off to accept full privatization than to agree to partial privatization.

To maintain subgame perfection, I therefore restrict my attention to $t$ such that full privatization Pareto dominates partial privatization. Notice, however, that given Assumption 4, the government agency would never choose to partially privatize the firm prior to $t^{s}(\lambda)$. Therefore, to be more precise, I will focus on $t$ such that full privatization at $t$ Pareto dominates partial privatization at $\max \left\{t, t^{s}(\lambda)\right\}$. Define $t_{0}^{\prime}$ as the new "starting point" where full privatization begins to dominate partial privatization at $t^{s}(\lambda)$,

$$
P D V^{p}\left(t_{0}^{\prime}, 0\right)+P D W^{p}\left(t_{0}^{\prime}, 0\right)=P D V^{g}\left(t_{0}^{\prime} ; t^{s}(\lambda), \lambda\right)+P D W^{g}\left(t_{0}^{\prime} ; t^{s}(\lambda), \lambda\right) .
$$

Lemma 11 Suppose that Assumption 1 and 4 hold. $t_{0}^{\prime} \in\left(t_{0}, t^{s}(0)\right)$. Furthermore, full privatization is feasible and Pareto dominates partial privatization at $t$ if and only if $t \in\left[t_{0}^{\prime}, t_{11}(0)\right]$ 
in the following sense:

$$
\begin{array}{cl}
P D V^{p}(t, 0)+P D W^{p}(t, 0)>P D V^{g}\left(t ; t^{s}(\lambda), \lambda\right)+P D W^{g}\left(t ; t^{s}(\lambda), \lambda\right) & \text { for } t \in\left(t_{0}^{\prime}, t^{s}(\lambda)\right) \\
P D V^{p}(t, 0)+P D W^{p}(t, 0)>P D V^{p}(t, \lambda)+P D W^{p}(t, \lambda) & \text { for } t \in\left[t^{s}(\lambda), t_{11}(0)\right] .
\end{array}
$$

I divide $\left[t_{0}^{\prime}, t_{11}(0)\right]$ into two time intervals: $\left[t_{0}^{\prime}, t^{s}(\lambda)\right)$ and $\left[t^{s}(\lambda), t_{11}(0)\right]$. In the first time interval, the government agency may find it better off to privatize at $t$ instead of maintaining government ownership and partially privatizing the firm at $t^{s}(\lambda)$. This happens when the following condition holds

$$
s^{*} \geq P D V^{g}\left(t ; t^{s}(\lambda), \lambda\right)-P D V^{p}(t, 0) \text { for some } t \in\left[t_{0}^{\prime}, t^{s}(\lambda)\right) \text {. }
$$

In condition $(18), \check{s}^{p}(t, \lambda)$ denote the incentive compatible price at which the firm would be partially privatized. In the second time interval, the government agency may find itself in favor of full privatization instead of partial privatization at the same point of time. This happens under the condition:

$$
s^{*} \geq P D V^{p}(t, \lambda)-P D V^{p}(t, 0)+\check{s}^{p}(t, \lambda), \text { for some } t \in\left[t^{s}(\lambda), t_{11}(0)\right]
$$

Condition (18) and (19) imply the existence of prices affordable to the manager such that the government agency will be better off to fully privatize the firm at $t$. Given the fact that $t \in\left[t_{0}^{\prime}, t_{11}(0)\right]$, one of such prices can also make the manager better off. Accordingly, had privatization not taken place by $t$, full privatization would take place at $t$ despite the possibility of partial privatization. Furthermore, once full privatization were to be chosen at $t$ over partial privatization, partial privatization would never be chosen at any $\tau \in\left[t_{0}^{\prime}, t\right)$. This is simply because full privatization Pareto dominates partial privatization for any $\tau \in\left[t_{0}^{\prime}, t\right)$ (see Lemma 11).

Condition (18) and (19) thus define the two scenarios I analyze here.

Definition 1 The government agency is said to always prefer partial privatization to full privatization if neither condition (18) nor condition (19) holds. Vice versa, the government agency is said to prefer full privatization to partial privatization at some point if either of these two conditions holds.

Define $t^{f}$ as the largest point in time that satisfies either condition (18) or condition (19). $t^{f}$ is therefore the point in time beyond which partial privatization will take over. I can draw the following conclusion:

Proposition 7 Suppose Assumption 1, 4, and 5 hold. When the government agency can choose either full or partial privatization, the following happens: 
a) the firm will be fully privatized at $\min \left\{t^{f}, t^{s}(0)\right\}$ if either condition (18) or condition (19) holds; and

b) the firm will be partially privatized at $t^{s}(\lambda)$ otherwise.

Proposition 6 states that, despite the possibility of partial privatization, the firm will continue to be fully privatized as long as either condition (18) or (19) is satisfied and that the firm will be (fully) privatized prematurely if and only if condition (18) holds prior to $t^{s}(0)$ but not after and condition (19) does not hold. Part (a) of this proposition is illustrated in Figure 6. The upper panel of this figure demonstrates a situation where $t^{f}>t^{s}(0)$, and the lower panel indicates one where $t^{f}<t^{s}(0)$. In both panels, the bold curves represent the streams of subgame perfect prices $\tilde{s}^{p}(t, \beta)$ if the firm were to privatize at $t$, either fully $(\beta=0)$ or partially $(\beta=\lambda)$.

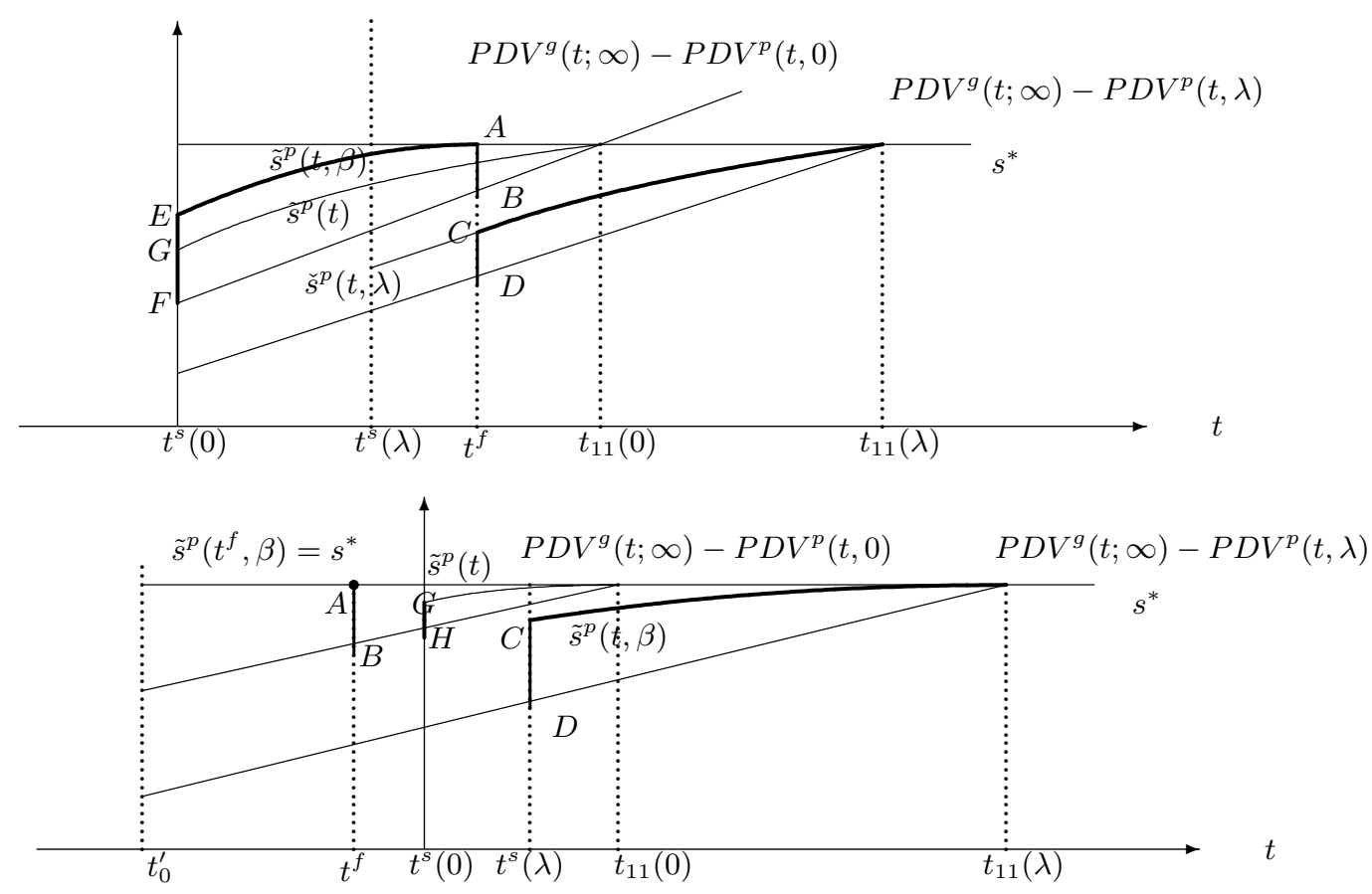

Figure 6: Full privatization with partial privatization possible

In the upper panel of Figure 6, the bold vertical lines $A B$ and $C D$ indicate the gains from full privatization and that from partial privatization for the government agency at $t^{f}$. $\overline{A B}=\overline{C D}$ because at $t^{f}$, the government agency is indifferent between full and partial privatization. In this case, the government agency begins to offer full privatization at $t^{s}(0)$, 
and continues to do so until $t^{f}$ at the price $\tilde{s}^{p}(t, 0)$, were the firm not privatized. After $t^{f}$, if the firm were still not privatized, the government agency would start to offer partial privatization at the price $\tilde{s}^{p}(t, \lambda)$. In equilibrium, the manager accepts the privatization offer at $t^{s}(0)$.

In the lower panel of this figure, the gains for the government agency from partial privatization at $t^{s}(\lambda)$ is represented by the bold vertical line $A B$. The bold vertical line $C D$ measures the corresponding gains from full privatization at $t^{f} . \overline{C D}$ equals $\overline{A B}$ with proper discounting, ${ }^{15}$ that is, the government agency is indifferent between full privatization at $t^{f}$ and waiting to partially privatize the firm at $t^{s}(\lambda)$. In this case, the government agency offers full privatization at the price $s^{*}$ at $t^{f}$. If rejected, the government agency will keep its ownership of the firm until $t^{s}(\lambda)$ upon which it would start to offer partial privatization at the price of $\tilde{s}^{p}(t, \lambda)$. In equilibrium, the manager accepts the offer at $t^{f}$.

As Figure 6 illustrates, the possibility of partial privatization helps increase the bargaining power of the government agency under full privatization. In this figure, the lighter curve $\tilde{s}^{p}(t)$ indicates the stream of privatization prices when partial privatization is not possible. In both the upper panel as well as the lower panel, the government agency grabs more gains from privatization with the possibility of partial privatization than without $(\overline{E F}>\overline{G F}$ in the upper panel and $\overline{E F}>\overline{G H}$ with proper discounting in the lower panel).

More generally, when either condition (18) or (19) holds, the government agency would charge $s^{*}$ for the firm at $t^{f}$ if the firm had not been privatized at that point. Since $t^{f}<$ $t_{11}(0),{ }^{16}$ and since the marginal rate of the price change (i.e., $\left.\frac{d \tilde{s}^{p}(t)}{d t}\right)$ is the same both with the possibility of partial privatization and without, the gains accruing to the government agency from full privatization must be at least as large with the possibility of partial privatization as without.

Corollary 1 Suppose Assumption 1 and 4 hold. Suppose in addition that either condition (18) or (19) is satisfied. Then the government agency receives at least as much gains from full privatization with the possibility of partial privatization as without. And it receives more

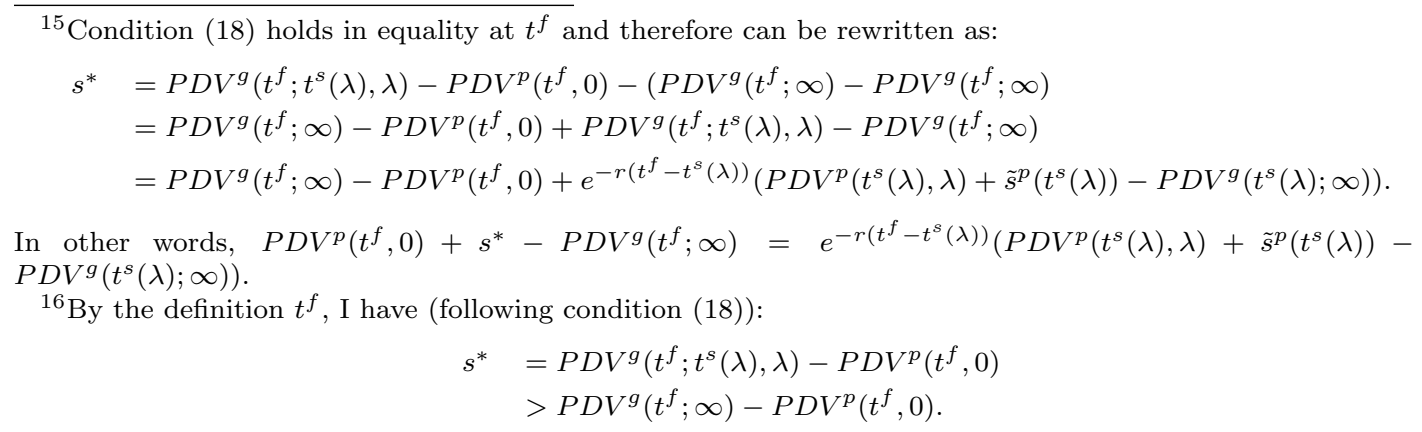


gains from full privatization if $t_{f}<t_{1}(0)$.

\subsection{Is partial privatization second best?}

As argued earlier, partial privatization helps relax the wealth constraint of the manager and make otherwise infeasible ownership transformation feasible. Thus, when full privatization is never feasible, partial privatization will take place at $t^{s}(\lambda)$ that is constrained efficient, as long as Assumption 5 holds. In this sense, partial privatization is the "second best" alternative in the presence of a wealth constraint.

However, as I will show next, the sheer possibility of partial privatization can also induce further efficiency loss. The additional efficiency loss takes place in three forms. The first form is highlighted in the lower panel of Figure 6 . The firm continues to be fully privatized in equilibrium yet the equilibrium timing becomes inefficient when partial privatization becomes possible (i.e., $t^{e}=t^{s}$ whereas $t^{e}(\beta)=t^{f}<t^{s}(0)$ ). In the second form, the firm is privatized prematurely at $t_{11}(0)<t^{s}(0)$ (see Proposition 6) without the possibility of partial privatization. When partial privatization becomes possible, the firm continues to be fully privatized but the equilibrium timing pushes further ahead at $t^{f}$. Since $t^{f}<t_{11}$ and since government ownership dominates private ownership prior to $t^{s}(0)$, earlier privatization reduces social surplus. In the third form, the firm is partially privatized in equilibrium at $t^{s}(\lambda)$ with the option of partial privatization, whereas without such an option, the firm is fully privatized at $\min \left\{t_{11}, t^{s}(0)\right\}$. If $t_{11}>t_{0}^{\prime}$, then by the definition of $t_{0}^{\prime}$, the long-term social surplus generated under full privatization will be larger than that generated under partial privatization.

The next corollary highlights the possibility for the first and the third form efficiency loss. The corollary follows that indicates the likelihood for the second and the third form of efficiency loss.

Corollary 2 Suppose that Assumption 1, 4, and 5 hold and that

$$
P D V^{g}\left(t^{s}(0) ; t^{s}(\lambda), \lambda\right)>P D V^{p}\left(t^{s}(0), 0\right) .
$$

Then there exists $s^{*}$ such that the firm is fully privatized at the efficient timing $t^{s}(0)$ without the option of partial privatization, but will not otherwise.

Corollary 3 Suppose Assumption 1, 4, and 5 hold and that

$$
P D V^{g}\left(t^{s}(0) ; t^{s}(\lambda), \lambda\right)>P D V^{p}\left(t^{s}(0), 0\right) .
$$

Then there exists $s^{*}$ such that the firm is fully privatized at $t_{11} \in\left(t_{0}^{\prime}, t^{s}(0)\right)$ without the option of partial privatization, but is either fully privatized before $t_{11}$ or partially privatized at $t^{s}(\lambda)$ 
when the option is available.

Why does the possibility of partial privatization induce further efficiency loss in ownership transformation? Interestingly, the additional efficiency loss is rooted in the fact that the manager has limited wealth. Ceteris paribus, the government agency prefers a partially privatized firm to a fully privatized one. Therefore, the ability to partially privatize the firm shifts the government agency's threat point in its favor during bargaining over full privatization. Such a shift allows the government agency to be more demanding for the transfer payment from the manager. Given that the manager has the limited wealth, additional efficiency loss thus ensues. This analysis thus serves as a cautionary reminder that partial privatization may not be a "second best" instrument for ownership transformation in the presence of buyers' wealth constraints.

\section{Conclusion}

The analysis in this paper is placed within the context of transition from central planning to market economy. It focuses on an institutional setting characterized by government failure on the one hand and a gradually developing product market on the other. With such an institutional setting in mind, I examined the trade-off between government ownership and private ownership and used such a trade-off to understand privatization from both a normative and a positive perspective. My analysis centered on the privatization of small-medium sized firms designed to empower insiders, in particular the management, and stop government intervention. By highlighting the many implications of the buyers' (i.e., the manager's) limited wealth on the privatization process, this analysis was able to shed lights on our existing understanding of privatization processes.

\subsection{Application to China}

To find the application of my analysis in real life, consider the experience of China over the last two decades. During the first decade of its economic reform, the Chinese experience seems to refute the conventional wisdom that government ownership is less efficient than private ownership and hence privatization is imperative. Shortly after it began economic reforms in the late 70's, China witnessed a rapid emergence of local government-owned enterprises, mostly in rural areas, known as township-village enterprises (TVEs). These enterprises spearheaded a remarkable growth of the economy in the following decade and subsequently changed the landscape of China's economy that was once dominated by state-owned firms. ${ }^{17}$ The share of these enterprises in the national industrial output increased from 9 percent in 1978 to 27

\footnotetext{
${ }^{17}$ See Byrd and Lin (1990) and Che and Qian (1998a) for more detailed descriptions of these enterprises.
} 
percent in 1993 (China Statistics Yearbook, 1994). During the same period of time, however, the development of private enterprises remained insignificant. By 1993 the private sector accounted for only about 12 percent of national industrial output.

Despite the early divergence, the recent Chinese experience appears to be converging to the global trend of privatization. Since mid 90's, local government-owned firms began a quiet and yet massive privatization, and by year 2000, more than 80 percent of TVEs had undertaken some form of privatization (China Rural Enterprise Yearbook 2001). By year 2000, the government share in the total assets of rural industrial firms (defined in China as including both rural private firms and TVEs) was around 40 percent, dropped by 6 percent in a single year, whereas the share of private investors (both domestic and foreign) reached 34 percent. ${ }^{18}$ Meanwhile the private sector expanded rapidly. Private firms were reportedly to be solely responsible for the growth in the sales revenue and the value added of rural enterprises for the year 2000 (China Rural Enterprise Yearbook 2001). The share of private firms in the national industrial output had jumped from 12 percent in 1993 to 34 percent in 1998. By 1998, 33 percent of GDP were contributed by private firms (International Finance Corporation 2000).

All these have happened while an adequate system of checks and balances continues to be absent from the Chinese political landscape. Without fundamental political reform in China, corruption has become "endemic" (Transition Newsletter 1995) during the process of economic liberalization and fiscal decentralization, despite continued efforts by the central government to crack down corruption committed by local government officials (Li 2002). The 1999 Transparency International Corruption Perception Index ranked the degree of corruption in China in the same group as that in Belarus and Mexico, falling far behind other transition and developing economies such as Hungary, Czech Republic, Namibia, or South Africa (http://www.transparency.org/cpi/1999/cpi1999.html).

Meanwhile, beginning from virtual non-existence, product markets developed quickly in China. This development helped drive the evolution of ownership structures in the non-state sector. When economic reforms first took place in China during the late 70's and early 80's, a significant portion of resources were still allocated through government command (Lin etc 1996). In rural areas, local government authorities controlled, or had better access to, products that are essential for firm operations (Chang and Wang 1994, Che and Qian 1998a). ${ }^{19}$ Many have attributed government ownership of these rural industrial enterprises to the control by

\footnotetext{
${ }^{18}$ Chen and Rozelle (1999), Brandt, Li, and Roberts (2001), and Sun (2002) also documented the privatization trend among TVEs.

${ }^{19}$ The early product market development in China was characterized by the so-called dual-track system (Lau, Qian, and Roland 2000). The dual track system was a hybrid resource allocation mechanism under which transitional central planning (the plan track) and the emerging product market (the market track) co-existed. Products in the plan track were artificially underpriced whereas products in the market track were transacted at market clearing prices. While firms in the non-state sector were mostly precluded from the plan track, they had often benefited from official diversion conducted by government officials who diverted the in-plan resources under their control to the market track ( $\mathrm{Li} 2002$ ).
} 
local authorities over "critical inputs" (Chang and Wang 1994, Naughton 1994, Che and Qian 1998a). After a decade of efforts, however, China made significant strides in liberalizing product markets during the last two decades. By 1990, there were still about 64 percent of intermediate products in China that were government regulated. However, just five years later, more than 80 percent of intermediate products were placed through markets (Tenev, Zhang, and Brefort 2002). Several authors have noted that the role of local government-owned enterprises has become less prominent in areas with better developed product markets (Jin and Qian 1998, Chen and Rozselle 1999).

Much of the privatization taking place within China's non-state sector involves de facto management buy-outs (Chen and Rozelle 1999, Brandt, Li, and Roberts 2000). The pattern is mostly a result of the fact that these enterprises are relatively small in size and highly localized. It is also because over the years of their development, these firms have grown dependent on the existing managerial talents, which are relatively scarce in China's rural society. Withstanding the product market development, the financial system remains underdeveloped in China. To date, four state-owned banks continue to dominate China's financial sector with an 80 percent of market share (Bonin 1999). A decade since its inception, the equity market remains dysfunctional, financing merely 2 percent of investment in 2001 (Economist 2003). Although the private sector contributes to more than 30 percent of GDP, the share of working capital loans from banks and other financial institutions outstanding to the private sector was still less than 1 percent by the end of 1998 (International Finance Corporation 2000). Indeed, researches haver found private firms to be discriminated by state-owned banks in their lending policies (Brandt and Li 2002).

Limited research has been done with respect to the post-privatization performance of these firms. A few existing empirical works seem to confirm what my analysis has revealed. For instance, Sonobe and Otsuka (2003) showed that, while the productivity of TVEs were significantly improved after recent privatization, such improvement came only after a few years after privatization. The same phenomenon was documented by Li and Rozelle (2000).

\subsection{Some possible extensions}

This paper analyzes a rich set of questions concerning government and private ownership as well as those related to privatization. However, due to the space limit, I am not able to elaborate on several issues that some readers may find interesting. Take the case where only full privatization is allowed for example, one can show that, the more likely does the government agency hold a laissez-faire attitude towards the business (i.e., when $\gamma$ is larger), the more likely will privatization take place prematurely. This is because a larger $\gamma$ increases the social surplus under government ownership on the one hand, and makes government ownership more attractive to the government agency on the other. Both factors tend to make 
it more likely that the wealth constraint is binding in type I at $t^{s}$. One can also show that, the faster the product market develops, the more likely will it be for the wealth constraint to be binding in type I. This implies that there is a trade-off in the product market development. A faster product market development means that privatization ought to take place earlier, but it also means that the timing of privatization will more likely to be inefficient, given the presence of buyers' wealth constraints.

This paper has considered only the scheme of insider privatization, in particular, privatizing the firm to the manager. I justify this focus by assuming that the manager is indispensable to the firm. Nevertheless, even under such a circumstance, it may still make sense for the government agency to sell the firm to rich outsiders as a way to circumvent the manager's wealth constraint. Given the space limit, I did not examine such an alternative, although I believe this is an interesting topic that is worth pursuing. In particular, privatizing to outsiders is likely to be followed with further ownership transformation, when the management is indispensable to the firm and remains the factor to be motivated. That is, after they acquire the firm from the government, outsiders may negotiate with the management and transfer ownership rights to the management. Addressing the issue of outsider privatization in this context may therefore help highlight the following question in the spirit of Coase: Does to whom the firm is initially privatized matter? 


\section{Appendix}

\section{Proof of Lemma 2}

Given Lemma 1, the proof of the existence of a separating equilibrium and that of uniqueness (using the intuitive criterion test) are standard. What I will focus on in this proof is the claim that $B^{g}\left(\theta_{h}\right)<B^{g}\left(\theta_{l}\right)$. To see this, notice that in a separating equilibrium, the following truth-telling constraint for the $\theta_{l}$ type must hold: $v^{g}\left(a_{1}^{g}(\rho=0), B^{g}\left(\theta_{l}\right) \mid \theta_{l}\right) \geq v^{g}\left(a_{1}^{g}(\rho=1), B^{g}\left(\theta_{h}\right) \mid \theta_{l}\right)$, or

$$
(1-\lambda) R_{1}\left(a_{1}^{g}(\rho=0) \mid \theta_{l}\right)+B^{g}\left(\theta_{l}\right) \geq(1-\lambda) R_{1}\left(a_{1}^{g}(\rho=1) \mid \theta_{l}\right)+B^{g}\left(\theta_{h}\right) .
$$

Since the ex post managerial effort is increasing in $\rho,(1-\lambda) R_{1}\left(a_{1}^{g}(\rho=0) \mid \theta_{l}\right)<(1-\lambda) R_{1}\left(a_{1}^{g}(\rho=1) \mid \theta_{l}\right)$. I therefore have $B^{g}\left(\theta_{l}\right)>B^{g}\left(\theta_{h}\right)$.

Proof of Proposition 1 I have shown (see equation (1)) that the government agency exploits fully its bargaining power under private ownership and the manager obtains no rents. In this proof, I show that the government agency will not do so under government ownership when $\theta=\theta_{h}$ and hence

$$
w_{1}^{g}(\rho=1)>\mu w_{0}^{g}(\rho=1) .
$$

To see this, notice that in the separating equilibrium, the individual rationality constraints for the manager when $\theta=\theta_{h}$ and when $\theta=\theta_{l}$ are

$$
w_{1}^{g}(\rho=1) \geq \mu w_{0}^{g}(\rho=1) \text {, and } w_{1}^{g}(\rho=0) \geq \mu w_{0}^{g}(\rho=0),
$$

respectively, where

$$
\begin{aligned}
w_{1}^{g}(\rho=1) & =\lambda R_{1}\left(a_{1}^{g}(\rho=1) \mid \theta_{h}\right)-c\left(a_{1}^{g}(\rho=1)\right)-B^{g}\left(\theta_{h}\right), \\
w_{1}^{g}(\rho=0) & =\lambda R_{1}\left(a_{1}^{g}(\rho=0) \mid \theta_{l}\right)-c\left(a_{1}^{g}(\rho=0)\right)-B^{g}\left(\theta_{l}\right), \\
w_{0}^{g}(\rho=1) & =\lambda R_{0}\left(a_{0}^{g}(\rho=1) \mid \theta_{h}\right)-c\left(a_{0}^{g}(\rho=1)\right), \text { and } \\
w_{0}^{g}(\rho=0) & =\lambda R_{0}\left(a_{0}^{g}(\rho=0) \mid \theta_{l}\right)-c\left(a_{0}^{g}(\rho=0)\right)
\end{aligned}
$$

are the ex post payoffs of the manager under the posterior belief $\rho$ when the product is either acquired from the government agency or from the market. Therefore, $w_{1}^{g}(\rho=1)>\mu w_{0}^{g}(\rho=1)$ if and only if:

$$
B^{g}\left(\theta_{h}\right)<\lambda R_{1}\left(a_{1}^{g}(\rho=1) \mid \theta_{h}\right)-c\left(a_{1}^{g}(\rho=1)\right)-\mu\left[\lambda R_{0}\left(a_{0}^{g}(\rho=1) \mid \theta_{h}\right)-c\left(a_{0}^{g}(\rho=1)\right)\right] .
$$

I use contradiction to show that condition (21) holds. Notice that the government-regulated product, the laissez-faire attitude of the government agency, and the ex post managerial effort are all complements to each other (Assumption 1). Hence, I have:

$$
\begin{aligned}
& \lambda R_{1}\left(a_{1}^{g}(\rho=1) \mid \theta_{h}\right)-c\left(a_{1}^{g}(\rho=1)\right)-\left[\lambda R_{1}\left(a_{1}^{g}(\rho=0) \mid \theta_{l}\right)-c\left(a_{1}^{g}(\rho=0)\right)\right] \\
& \quad>\lambda R_{0}\left(a_{0}^{g}(\rho=1) \mid \theta_{h}\right)-c\left(a_{1}^{g}(\rho=1)\right)-\left[\lambda R_{0}\left(a_{0}^{g}(\rho=0) \mid \theta_{l}\right)-c\left(a_{0}^{g}(\rho=0)\right)\right] .
\end{aligned}
$$


In other words,

$$
\begin{aligned}
& \lambda R_{1}\left(a_{1}^{g}(\rho=1) \mid \theta_{h}\right)-c\left(a_{1}^{g}(\rho=1)\right)-\mu\left[\lambda R_{0}\left(a_{0}^{g}(\rho=1) \mid \theta_{h}\right)-c\left(a_{1}^{g}(\rho=1)\right)\right] \\
& \quad>\lambda R_{1}\left(a_{1}^{g}(\rho=0) \mid \theta_{l}\right)-c\left(a_{1}^{g}(\rho=0)\right)-\mu\left[\lambda R_{0}\left(a_{0}^{g}(\rho=0) \mid \theta_{l}\right)-c\left(a_{0}^{g}(\rho=0)\right)\right] .
\end{aligned}
$$

Since the individual rationality constraint is binding when $\theta=\theta_{l}$ in the separating equilibrium,

$$
B^{g}\left(\theta_{l}\right)=\lambda R_{1}\left(a_{1}^{g}(\rho=0) \mid \theta_{l}\right)-c\left(a_{1}^{g}(\rho=0)\right)-\mu\left[\lambda R_{0}\left(a_{0}^{g}(\rho=0) \mid \theta_{l}\right)-c\left(a_{0}^{g}(\rho=0)\right)\right] .
$$

Therefore, if condition (21) does not hold, it would imply (in conjunction with condition (22) and (23)) that $B^{g}\left(\theta_{h}\right)>B^{g}\left(\theta_{l}\right)$, contradicting to Lemma 2. I therefore conclude: $w_{1}^{g}(\rho=1)>\mu w_{0}^{g}(\rho=1)$.

\section{Proof of Lemma 3}

Let $S^{g}(e)$ and $S^{p}(e)$ denote the social surplus as a function of the ex ante managerial effort $e$ under government ownership and under private ownership respectively:

$$
\begin{aligned}
& S^{p}(e)=e\left(R_{1}\left(a^{p}\right)-c\left(a^{p}\right)\right)-c(e), \\
& S^{g}(e)=e\left[\gamma R_{1}\left(a^{g}(\rho=1) \mid \theta_{h}\right)-c\left(a^{g}(\rho=1)\right)+(1-\gamma) R_{1}\left(a^{g}(\rho=0) \mid \theta_{l}\right)-c\left(a^{g}(\rho=0)\right)\right]-c(e) .
\end{aligned}
$$

By the definitions of $S^{g}$ and $S^{p}, S^{g}=S^{g}\left(e^{g}\right)$ and $S^{p}=S^{p}\left(e^{p}\right)$. Because private ownership is more efficient than government ownership ex post, these two social surplus functions satisfy a single-crossing property:

$$
\partial S^{p}(e) / \partial e>\partial S^{g}(e) / \partial e
$$

for all $e$ and $S^{p}(e)=S^{g}(e)$ if and only if $e=0$. These observations are illustrated in the next figure.

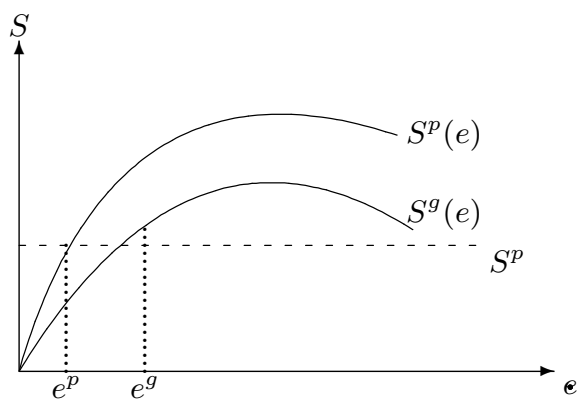

Figure 7: Social Surplus under Private and Government Ownership

Given the strict convexity of $c(e)$, both $S^{g}(e)$ and $S^{p}(e)$ are strictly concave in $e$. Furthermore, both $e^{p}$ and $e^{g}$, fall short of the second best effort levels that maximize $S^{g}(e)$ and $S^{p}(e)$ respectively; in other words, both $\partial S^{p}\left(e^{p}\right) / \partial e$ and $\partial S^{g}\left(e^{g}\right) / \partial e$ are positive. Therefore, $S^{g}>S^{p}$ only if government ownership improves ex ante managerial incentives significantly, or $e^{g}>e^{p}$ as shown in Figure 7 . 


\section{Proof of Lemma 4}

The first order conditions for $e^{g}$ and $e^{p}$ are:

$$
\frac{d c\left(e^{g}\right)}{d e}=\gamma w_{1}^{g}(\rho=1)+\gamma w_{1}^{g}(\rho=0), \text { and } \frac{d c\left(e^{p}\right)}{d e}=w_{1}^{p}
$$

respectively. Following equation (1), I have:

$$
\frac{\partial e^{p}}{\partial \mu}=\frac{w_{0}^{p}}{d^{2} c / d e^{p 2}}
$$

Using the definitions of $w_{1}^{g}(\rho=1)$ and $w_{1}^{g}(\rho=0)$ (see the proof of Proposition1), I also have:

$$
\begin{aligned}
\frac{\partial e^{g}}{\partial \mu} & =\frac{\partial\left[-\gamma B^{g}\left(\theta_{h}\right)-(1-\gamma) B^{g}\left(\theta_{l}\right)\right]}{\partial \mu} / \frac{d^{2} c}{d e^{p^{2}}} \\
& =\frac{\partial\left[-\gamma\left(B^{g}\left(\theta_{h}\right)-B^{g}\left(\theta_{l}\right)\right)-B^{g}\left(\theta_{l}\right)\right]}{\partial \mu} / \frac{d^{2} c}{d e^{p^{2}}} .
\end{aligned}
$$

In a sequential equilibrium that survives the intuitive criterion test, the truth-telling condition for $\theta_{l}$ type is binding. That is, condition (20) holds in equality, implying:

$$
B^{g}\left(\theta_{h}\right)-B^{g}\left(\theta_{l}\right)=(1-\lambda) R_{1}\left(a_{1}^{g}(\rho=0) \mid \theta_{l}\right)-(1-\lambda) R_{1}\left(a_{1}^{g}(\rho=1) \mid \theta_{l}\right) .
$$

Substituting (27) and (23) into (26), I have:

$$
\frac{\partial e^{g}}{\partial \mu}=\frac{w_{0}^{g}(\rho=0)}{d^{2} c / d e^{p 2}}
$$

Comparing (25) and (28), I note that $w_{0}^{g}(\rho=0)<w_{0}^{p}$. Furthermore, given Assumption 2, $\partial^{2} c / \partial\left(e^{g}\right)^{2} \geq \partial^{2} c / \partial\left(e^{p}\right)^{2}$ when $e^{p} \leq e^{g}$. Therefore, I conclude: $\partial e^{g} / \partial \mu<\partial e^{p} / \partial \mu$ when $e^{g} \geq e^{p}$.

\section{Proof of Proposition 2}

I show first that $\frac{\partial S^{p}}{\partial \mu}>\frac{\partial S^{g}}{\partial \mu}$ for $\mu^{s}$ such that $S^{p}\left(\mu^{s}\right)=S^{g}\left(\mu^{s}\right)$. Notice that these derivatives can be written as $\frac{\partial S^{g}}{\partial \mu}=\frac{\partial S^{g}}{\partial e^{g}} \frac{\partial e^{g}}{\partial \mu}$, $\frac{\partial S^{p}}{\partial \mu}=\frac{\partial S^{p}}{\partial e^{p}} \frac{\partial e^{p}}{\partial \mu}$. I evaluate these derivatives at $\mu=\mu^{s}$. Since $S^{p}\left(\mu^{s}\right)=S^{g}\left(\mu^{s}\right), e^{p}\left(\mu^{\prime}\right)<e^{g}\left(\mu^{\prime}\right)$ (Lemma 3) and hence $\frac{\partial e^{p}}{\partial \mu}>\frac{\partial e^{g}}{\partial \mu}$ (Lemma 4). Furthermore, given the single-crossing property (24) of the social surplus functions under the two ownership forms and the concavity of the social surplus functions, I have:

$$
\frac{\partial S^{p}}{\partial e^{p}}>\frac{\partial S^{p}}{\partial e^{g}}>\frac{\partial S^{g}}{\partial e^{g}}
$$

Therefore, $\frac{\partial S^{p}}{\partial \mu}>\frac{\partial S^{g}}{\partial \mu}$ at $\mu=\mu^{s}$.

Next, I show that there exists $\mu^{s}$ such that $S^{p}\left(\mu^{s}\right)=S^{g}\left(\mu^{s}\right)$. This is simply because that $S^{g}>S^{p}$ if $\mu=0$ and that $S^{p}>S^{g}$, if $\mu=1$.

\section{Proof of Lemma 6}

Differentiating $W^{p}-W^{g}$ with respect to $\mu$ and using the envelope theorem, I have:

$$
\partial W^{p} / \partial \mu-\partial W^{g} / \partial \mu=e^{p} \frac{\partial w_{1}^{p}}{\partial \mu}-e^{g} \frac{\partial\left[\gamma w_{1}^{g}(\rho=1)+(1-\gamma) w_{1}^{g}(\rho=0)\right]}{\partial \mu} .
$$


Using the definitions of $w_{1}^{g}(\rho=1)$ and $w_{1}^{g}(\rho=0)$ (see the proof of Proposition1), I have:

$$
\frac{\partial\left[\gamma w_{1}^{g}(\rho=1)+(1-\gamma) w_{1}^{g}(\rho=0)\right]}{\partial \mu}=\frac{\partial\left[-\gamma B^{g}\left(\theta_{h}\right)-(1-\gamma) B^{g}\left(\theta_{l}\right)\right]}{\partial \mu}
$$

Following the proof of Lemma 4, I have:

$$
\frac{\partial\left[-\gamma B^{g}\left(\theta_{h}\right)-(1-\gamma) B^{g}\left(\theta_{l}\right)\right]}{\partial \mu}=w_{0}^{g}(\rho=0) .
$$

Meanwhile, $\frac{\partial w_{1}^{p}}{\partial \mu}=w_{0}^{p}$ according to equation (1). Since $e^{p} \geq e^{g}$ and $w_{0}^{p}>w_{0}^{g}(\rho=0)$, I conclude $\partial W^{p} / \partial \mu-\partial W^{g} / \partial \mu>0$.

\section{Proof of Lemma 8}

The necessary part of the claim is based on the fact that condition (5) is derived by combining condition (4) and condition (3) together.

For the sufficient part, I show first that privatization Pareto dominates no privatization at $t$ if and only if $t \geq t_{0}$. Naturally, this is true when $t \geq t^{s}$. For $t \in\left[t_{0}, t^{s}\right)$, notice that because $t_{0}<t^{s}$, $S^{p}\left(t_{0}\right)<S^{g}\left(t_{0}\right)$. Since

$$
\begin{aligned}
\frac{d\left(P D W^{p}\left(t_{0}\right)+P D V^{p}\left(t_{0}\right)\right)}{d t} & =r\left(P D W^{p}\left(t_{0}\right)+P D V^{p}\left(t_{0}\right)\right)-S^{p}\left(t_{0}\right) \text { and } \\
\frac{d\left(P D W^{g}\left(t_{0} ; \infty\right)+P D V^{p}\left(t_{0} ; \infty\right)\right)}{d t} & =r\left(P D W^{g}\left(t_{0} ; \infty\right)+P D V^{p}\left(t_{0} ; \infty\right)\right)-S^{g}\left(t_{0}\right),
\end{aligned}
$$

I have $\frac{d\left(P D W^{p}\left(t_{0}\right)+P D V^{p}\left(t_{0}\right)\right)}{d t}>\frac{d\left(P D W^{g}\left(t_{0} ; \infty\right)+P D V^{p}\left(t_{0} ; \infty\right)\right)}{d t}$. Further induction then establishes that $P D W^{p}(t)+P D V^{p}(t) \geq P D W^{g}(t ; \infty)+P D V^{g}(t ; \infty)$ for $t \in\left[t_{0}, t^{s}\right]$.

Since privatization can take place only if it Pareto dominates no privatization, the observation above implies that privatization can take place only after $t_{0}$. Conditional on $t \geq t_{0}$, it is easy to show that there exists $s^{p}(t)$ that satisfies (2), (3), and (4) when condition (5) holds.

\section{Proof of Lemma 9}

The first part of this proposition follows from the fact that for $t \geq t_{0}$,

$$
P D W^{p}(t)+P D V^{p}(t) \geq P D W^{g}(t ; \infty)+P D V^{g}(t ; \infty) .
$$

The second and the third part are derived from the same logic, since $W^{p}(t)-W^{g}(t)$ has the property that it is increasing in $t$ for all $t \geq t^{s}$ such that $W^{p}(t)>W^{g}(t)$ (Lemma 6). To avoid repetition, I therefore prove only the third part.

Notice first that $\frac{d\left(P D V^{g}(t ; \infty)-P D V^{p}(t)\right)}{d t}=r\left(P D V^{g}(t ; \infty)-P D V^{p}(t)\right)-\left(V^{g}(t)-V^{p}(t)\right)$. The derivative is positive at $t$ if $V^{g}(t) \leq V^{p}(t)\left(P D V^{g}(t ; \infty)-P D V^{p}(t)>0\right.$ since by assumption the wealth constraint is binding in type I at $t)$. If $V^{g}(t)>V^{p}(t)$ instead, then by the assumption that $V^{g}(t)-V^{p}(t)$ is increasing in $t$ for all $t \geq t^{s}$ such that $V^{g}(t)>V^{p}(t)$, I have:

$$
r\left(P D V^{g}(t ; \infty)-P D V^{p}(t)\right)>V^{g}(t)-V^{p}(t) .
$$


Therefore, the derivative is positive as well. Since $\frac{d\left(P D V^{g}(t ; \infty)-P D V^{p}(t)\right)}{d t}>0$ for all $t \geq t^{s}$, the wealth constraint is binding in type I for any $\tau>t$ when it is binding in type I at $t \geq t^{s}$.

\section{Proof of Lemma 10}

Whether the firm is partially or fully privatized, the government agency will no longer restrain itself from rent seeking when dealing with such a firm. Accordingly, all the ex post rents accrue to the government agency through the illicit fee. Therefore,

$$
V^{p}(t, \beta)=e^{p}(t, \beta)\left[R_{1}\left(a^{p}(\beta)\right)-c\left(a^{p}(\beta)\right)-w_{0}^{p}(\beta)\right]
$$

When $c(e)$ is quadratic, $e^{p}(t, \beta)=\arg \max _{e}\left[e \mu(t) w_{0}^{p}(\beta)-c(e)\right]$ is linear in $\mu(t) w_{0}^{p}(\beta)$. Therefore, given part a) of Assumption $4, V^{p}(t, \lambda)>V^{p}(t, 0)$ if and only if part b) of Assumption 4 holds. That $V^{p}(t, \lambda)>V^{p}(t, 0)$ for any $t$ in turn implies the second claim: $t_{11}(\lambda)>t_{11}(0)$. The last claim of this lemma is derived from part $\mathrm{b}$ ) of Assumption 4 and the fact that, when $c(e)$ is quadratic,

$$
\begin{aligned}
& \frac{d\left(V^{p}(t, \lambda)-V^{p}(t, 0)\right)}{d t} \\
& =\frac{d \mu}{d t}\left\{w_{0}^{p}(\lambda)\left[R_{1}\left(a^{p}(\lambda)\right)-c\left(a^{p}(\lambda)\right)-w_{0}^{p}(\lambda)\right]-w_{0}^{p}(0)\left[R_{1}\left(a^{p}(0)\right)-c\left(a^{p}(0)\right)-w_{0}^{p}(0)\right]\right\} .
\end{aligned}
$$

\section{Proof of Lemma 11}

First, I show that $t_{0}^{\prime}<t^{s}(0)$. This is because (1) at $t^{s}(0)$ it is socially optimal for the firm to transform from government ownership to a fully privatized one and (2) a fully privatized firm always generates a larger social surplus than a partially privatized firm. Therefore at $t^{s}(0)$ transforming government ownership to a fully privatized one must dominate keeping the firm under government ownership till $t^{s}(\lambda)$ and then transforming it to a partially privatized firm.

Next, I show that $t_{0}^{\prime}>t_{0}$. To see this, notice that because $t_{0}^{\prime}<t^{s}(0)$ and therefore $S^{p}\left(t_{0}^{\prime}\right)<$ $S^{g}\left(t_{0}^{\prime}\right)$, I have:

$$
\frac{d\left(P D V^{p}\left(t_{0}^{\prime}, 0\right)+P D W^{p}\left(t_{0}^{\prime}, 0\right)\right)}{d t}>\frac{d\left(P D V^{g}\left(t_{0}^{\prime} ; t^{s}(\lambda), \lambda\right)+P D W^{g}\left(t_{0}^{\prime} ; t^{s}(\lambda)\right)\right.}{d t} .
$$

In addition, for any $t<t^{s}(\lambda)$,

$$
P D V^{p}\left(t ; t^{s}(\lambda), \lambda\right)+P D W^{p}\left(t ; t^{s}(\lambda), \lambda\right)>P D V^{g}(t ; \infty)+P D W^{g}(t ; \infty) .
$$

Combining these two observations together, I can conclude that

$$
P D V^{p}\left(t_{0}^{\prime}, 0\right)+P D W^{p}\left(t_{0}^{\prime}, 0\right)>P D V^{g}\left(t_{0}^{\prime} ; \infty\right)+P D W^{g}\left(t_{0}^{\prime} ; \infty\right),
$$

or $t_{0}^{\prime}>t_{0}$.

Since a fully privatized firm always generates more social surplus than a partially privatized one, it is easy to see that

$$
P D V^{p}(t, 0)+P D W^{p}(t, 0)>P D V^{p}(t, \lambda)+P D W^{p}(t, \lambda)
$$


for $t \in\left[t^{s}(\lambda), t_{11}(0)\right]$. Notice that full privatization is not feasible beyond the point $t_{11}(0)$.

Since in addition a fully privatized firm also generates more social surplus than a government owned firm when $t>t^{s}(0)$, I have:

$$
P D V^{p}(t, 0)+P D W^{p}(t, 0)>P D V^{g}\left(t ; t^{s}(\lambda), \lambda\right)+P D W^{g}\left(t ; t^{s}(\lambda), \lambda\right)
$$

for $t \in\left[t^{s}(0), t^{s}(\lambda)\right)$.

To see why full privatization at $t$ Pareto dominates partial privatization at $t^{s}(\lambda)$ for $t \in\left[t_{0}^{\prime}, t^{s}(0)\right)$, notice that

$$
\frac{d\left(P D V^{p}\left(t_{0}^{\prime}, 0\right)+P D W^{p}\left(t_{0}^{\prime}, 0\right)\right)}{d t}>\frac{d\left(P D V^{g}\left(t_{0}^{\prime} ; t^{s}(\lambda), \lambda\right)+P D W^{g}\left(t_{0}^{\prime} ; t^{s}(\lambda), \lambda\right)\right.}{d t}
$$

as $S^{p}\left(t_{0}^{\prime}, 0\right)<S^{g}\left(t_{0}^{\prime}\right)$. Further induction then establishes that

$$
P D V^{p}(t, 0)+P D W^{p}(t, 0)>P D V^{g}\left(t ; t^{s}(\lambda), \lambda\right)+P D W^{g}\left(t ; t^{s}(\lambda), \lambda\right)
$$

for $t \in\left(t_{0}^{\prime}, t^{s}(0)\right)$ using the fact that $S^{p}(t, 0)<S^{g}(t)$ in this case.

\section{Proof of Corollary 2}

Without the option of partial privatization, the equilibrium timing of privatization will be efficient as long as the wealth constraint is not binding in type I at $t^{s}(0)$ :

$$
s^{*} \geq P D V^{g}\left(t^{s}(0) ; \infty\right)-P D V^{p}\left(t^{s}(0), 0\right) .
$$

With the option of partial privatization, the equilibrium timing will not be at $t^{s}(0)$ if neither condition (18) holds for any $t \in\left[t^{s}(0), t^{s}(\lambda)\right)$ nor does condition (19) for any $t \in\left[t^{s}(\lambda), t_{11}(\lambda)\right]$. That is, for $t \in\left[t^{s}(0), t^{s}(\lambda)\right)$,

$$
s^{*}<P D V^{g}\left(t ; t^{s}(\lambda), \lambda\right)-P D V^{p}(t, 0)
$$

and for $t \in\left[t^{s}(\lambda), t_{11}(\lambda)\right]$,

$$
s^{*}<P D V^{p}(t, \lambda)-P D V^{p}(t, 0)+\check{s}^{p}(t, \lambda) .
$$

To see this, notice first that because $P D V^{p}\left(t^{s}(0) ; t^{s}(\lambda), \lambda\right)>P D V^{g}\left(t^{s}(0) ; \infty\right)$ and $P D V^{g}\left(t^{s}(0) ; t^{s}(\lambda), \lambda\right)-$ $P D V^{p}\left(t^{s}(0), 0\right)>0$, there exists $s^{*}>0$ such that:

$$
P D V^{g}\left(t^{s}(0) ; \infty\right)-P D V^{p}\left(t^{s}(0), 0\right) \leq s^{*}<P D V^{g}\left(t^{s}(0) ; t^{s}(\lambda), \lambda\right)-P D V^{p}\left(t^{s}(0), 0\right) .
$$

It turns out, as I will show next, that $P D V^{g}\left(t ; t^{s}(\lambda), \lambda\right)-P D V^{p}(t, 0)$ is increasing in $t$ for $t \geq t^{s}(0)$. Accordingly, when $s^{*}<P D V^{g}\left(t^{s}(0) ; t^{s}(\lambda), \lambda\right)-P D V^{p}\left(t^{s}(0), 0\right)$,

$$
s^{*}<P D V^{g}\left(t^{s}(0) ; t^{s}(\lambda), \lambda\right)-P D V^{p}\left(t^{s}(0), 0\right) \text { for } t \in\left(t^{s}(0), t^{s}(\lambda)\right)
$$


I now show that $P D V^{g}\left(t ; t^{s}(\lambda), \lambda\right)-P D V^{p}(t, 0)$ is increasing in $t$ for $t \geq t^{s}(0)$. Note that

$$
\frac{d\left(P D V^{g}\left(t ; t^{s}(\lambda), \lambda\right)-P D V^{p}(t, 0)\right)}{d t}=r\left(P D V^{g}\left(t ; t^{s}(\lambda), \lambda\right)-P D V^{p}(t, 0)\right)-\left(V^{g}(t)-V^{p}(t)\right) .
$$

This derivative, evaluated at $t^{s}(0)$, is positive as $V^{p}\left(t^{s}(0)\right)>V^{g}\left(t^{s}(0)\right)$ and $P D V^{p}\left(t^{s}(0) ; t^{s}(\lambda), \lambda\right)-$ $P D V^{p}\left(t^{s}(0), 0\right)>0$. To demonstrate that the derivative is also positive for $t \in\left(t^{s}(0), t^{s}(\lambda)\right)$, assume otherwise. In that case, there would exist $\tau \in\left[t^{s}(0), t^{s}(\lambda)\right)$ such that the derivative is zero at $\tau$ but positive prior to $\tau$ :

$$
r\left(P D V^{p}\left(\tau ; t^{s}(\lambda), \lambda\right)-P D V^{p}(\tau, 0)\right)=V^{g}(\tau)-V^{p}(\tau)
$$

Since the derivative is positive prior to $\tau$ and $P D V^{p}\left(t^{s}(0) ; t^{s}(\lambda), \lambda\right)-P D V^{p}\left(t^{s}(0), 0\right)>0$, I have $P D V^{p}\left(\tau ; t^{s}(\lambda), \lambda\right)-P D V^{p}(\tau, 0)>0$ and hence $V^{g}(\tau)>V^{p}(\tau)$ according to equation (29). However, following part c) of Lemma 10 and the fact that Assumption 3 holds under Assumption 4, one can conclude from $V^{g}(\tau)>V^{p}(\tau)$ that

$$
r\left(P D V^{g}\left(\tau ; t^{s}(\lambda), \lambda\right)-P D V^{p}(\tau, 0)\right)>V^{g}(\tau)-V^{p}(\tau)
$$

This contradicts equation (29). In other words, condition 18 does not hold for $t \in\left[t^{s}(0), t^{s}(\lambda)\right]$.

To show that condition (19) does not hold for $t \in\left(t^{s}(\lambda), t_{11}(\lambda)\right]$, notice first that $P D V^{g}\left(t ; t^{s}(\lambda), \lambda\right)-$ $P D V^{p}(t, 0)=P D V^{p}(t, \lambda)+\check{s}^{p}(t, \lambda)-P D V^{p}(t, 0)$ when $t=t^{s}(\lambda)$, and that $P D V^{p}(t, \lambda)+\check{s}^{p}(t, \lambda)-$ $P D V^{p}(t, 0)$ is increasing in $t$ as well. The monotonicity is derived as:

$$
\begin{aligned}
\frac{d\left(P D V^{p}(t, \lambda)+\check{s}^{p}(t, \lambda)-P D V^{p}(t, 0)\right)}{d t}= & r\left(P D V^{p}(t, \lambda)-P D V^{p}(t, 0)\right) \\
& -\left(V^{p}(t, \lambda)-V^{p}(t, 0)\right)+\frac{d \check{s}^{p}(t, \lambda)}{d t} .
\end{aligned}
$$

Following part c) of Lemma 10, $r\left(P D V^{p}(t, \lambda)-P D V^{p}(t, 0)\right)>V^{p}(t, \lambda)-V^{p}(t, 0)$. Moreover, $\frac{d \check{s}^{p}(t, \lambda)}{d t}>0$. Therefore, $\frac{d\left(P D V^{p}(t, \lambda)+\check{s}^{p}(t, \lambda)-P D V^{p}(t, 0)\right)}{d t}>0$.

\section{Proof of Corollary 3}

Recall that $V^{p}(t)>V^{p}(t)$ for $t \in\left[t\left(\mu_{1}^{g}\right), t^{s}(0)\right]$, where $t\left(\mu_{1}^{g}\right)$ is the point prior to $t^{s}$ where the government agency prefers for the first time a fully privatized firm to a government-owned one (Proposition ??). Given the assumption that $P D V^{g}\left(t^{s}(0) ; \infty\right)-P D V^{p}\left(t^{s}(0), 0\right)>0$, there exists $\tau \in\left(t\left(\mu_{1}^{g}\right), t^{s}(0)\right.$ such that $P D V^{g}(t ; \infty)-P D V^{p}(t, 0)$ is increasing in $t$ for $t \in\left(\tau, t^{s}(0)\right]$.

Restricting my attention to $t$ such that $t \in\left(\max \left\{t_{0}^{\prime}, \tau\right\}, t^{s}(0)\right]$, I have $P D V^{g}(t ; \infty)-P D V^{p}(t, 0)$ increasing in $t$ and full privatization at $t$ to Pareto dominate partial privatization at $t^{s}(\lambda)$. Since $P D V^{g}\left(t^{s}(0) ; \infty\right)-P D V^{p}\left(t^{s}(0), 0\right)>0$, there exists $s^{*}>0$ such that

$$
s^{*}=P D V^{g}\left(t_{11} ; \infty\right)-P D V^{p}\left(t_{11}, 0\right) \text { for some } t_{11} \in\left(\max \left\{t_{0}^{\prime}, \tau\right\}, t^{s}(0)\right) .
$$

In other words, with the option of partial privatization, full privatization is not feasible at $t^{s}(0)$, but is feasible at $t_{11}>t_{0}^{\prime}$, implying that it dominates partial privatization at $t^{s}(\lambda)$. When partial 
privatization is possible, however, there will be no full privatization at $t_{11}$ since

$$
P D V^{g}\left(t_{11} ; t^{s}(\lambda), \lambda\right)-P D V^{p}\left(t_{11}, 0\right)>P D V^{g}\left(t_{11} ; \infty\right)-P D V^{p}\left(t_{11}, 0\right)=s^{*} .
$$

As a result, the firm is either fully privatized prior to $t_{11}$ or partially privatized at $t^{s} \lambda$. In either case, it is less efficient than full privatization at $t_{11}$.

\section{References}

Aghion, Philippe and Oliver Blanchard (1998), "On Privatization Methods in Eastern Europe and Their Implications," Economics of Transition, v6, n1: 87-99.

Aghion, Philippe, Oliver Blanchard, and Robin Burgess (1994), "The Behavior of State Firms in Eastern Europe, Pre-Privatization," European Economic Review, v28, n6: 1327-1349.

Berglof, Erik and Patrick Bolton (2003), "The Great Divide and Beyond - Financial Architecture in Transition," mimeo, SITE, Stockholm School of Economics.

Bevan, Alan, Estrin, Saul, and Mark Schaffer (1999), "Determinants of Enterprise Performance During Transition," Center for Economic Reform and Transformation CERT working paper 99/03.

Biais, Bruno and Enrico Perotti (2002), "Machiavellian Underpricing," American Economic Review,

Bolton, Patrick, and Gerard Roland (1992), "Privatization Policies in Central and Eastern Europe," Economic Policy: A European Forum, v0, n15: 275-303.

Bonin, John (1999), "China's Banking Sector: Fragile Reed or Gradually Strengthening Pillar?" William Davidson Institute Discussion Paper, n249.

Boycko, Maxim, Andrei Shleifer, and Robert Vishny (1996), "A Theory of Privatization," Economic Journal, v106, n435: 309-19.

Brandt, Loren, and Hongbin Li (2002), "Bank Discrimination in Transition Economies: Ideology, Information or Incentives?" mimeo, University of Toronto.

Brandt, Loren, Hongbin Li, and Joanne Roberts (2001), "Why do Governments Privatize?" mimeo, University of Toronto.

Byrd and Q. Lin (eds.) (1990), China's Rural Industry: Structure, Development, and Reform, Oxford: Oxford University Press.

Cao, Yuanzheng, Yingyi Qian, and Barry Weingast (1999), "From Federalism, Chinese Style, to Privatization, Chinese Style," Economics of Transition, March 1999, 7(1), pp. 103-131. 
Chang, Chun and Yijiang Wang (1994), "The Nature of the Township Enterprise," Journal of Comparative Economics, v19, p.p. 434-452.

Che, Jiahua (2002), "Rent Seeking and Government Ownership of Firms: An Application to China's township- village enterprises," forthcoming Journal of Comparative Economics.

Che, Jiahua and Yingyi Qian (1998a), "Institutional Environment, Community Government, and Corporate Governance: Understanding China's Township-Village Enterprises," Journal of Law, Economics and Organization, v14, n1, 1-23.

Che, Jiahua and Yingyi Qian (1998b), "Insecure Property Rights and Government Ownership of Firms," Quarterly Journal of Economics, v113, n2, p.p. 467-96.

Chen Hongyi and Scott Rozelle (1999) "Leaders, Managers, and the Organization of Township and Village Enterprises in China," Journal of Development Economics 60, 2: 529-557.

China Rural Enterprise Yearbook, Beijing, China Agriculture Publishing House, 2001.

China Statistical Yearbook, Beijing: China Statistical Publishing House, 1994.

Chiu, Stephen (1998), "Noncooperative Bargaining, Hostage, and Optimal Asset Ownership," American Economic Review, v88, n4: 882-901.

Cho, Inkoo and David Kreps (1987), "Signaling Games and Stable Equilibria," Quarterly Journal of Economics, 102: 179-221.

De Meza, David and Ben Lockwood (1998), "Does Asset Ownership Always Motivate Managers? Outside Options and the Property Rights Theory of the Firm," Quarterly Journal of Economics, v113, n8: 361-386.

Debande, Olivier and Guido Friebel (1999), "A Positive Theory of Insider Privatization," William Davidson Institute, University of Michigan, working paper n39.

Demougin, Dominique and Hans-Werner Sinn (1994), "Privatization, Risk-Taking and the Communist Firm," Journal of Public Economics, v55, n2: 203-231.

Djankov, Simeon and Peter Murrell (2002), "Enterprise Restructuring in Transition: A quantitative survey," mimeo, University of Maryland, College Park, MD.

Economist (2003), "The Weakest Link: A survey of Asian finance," February 8th.

Grossman, Sandy and Oliver Hart (1986), "The Costs and Benefits of Ownership: A Theory of Vertical and Lateral Integration," Journal of Political Economy, v94, n4, p.p. 691-719.

Hart, Oliver and John Moore (1990), "Property Rights and the Nature of the Firm," Journal of Political Economy, v98, n6, p.p. 1119-58.

International Finance Corporation(2000), China's Emerging Private Enterprises: Prospects for the new century, International Finance Corporation, Washington D.C.. 
Jin, Hehui and Yingyi Qian (1998), "Public vs. Private Ownership of Firms: Evidence from Rural China," Quarterly Journal of Economics, v113, n3, p.p. 773-808.

Lau, Lawrence, Yingyi Qian, and Gerard Roland (2000), "Reform without Losers: An interpretation of China's dual track approach to transition," Journal of Political Economy, v108, n1: 120-143.

Li, David (1996), "A theory of Ambiguous Property Rights in Transition Economies" Journal of Comparative Economics, v23, n1, p.p. 1-19.

Li, Hongbin and Scott Rozelle (2000), "Saving or Stripping Rural Industry: An analysis of privatization and efficiency in China," Agriculture Economics, v23, n3, 241-252.

Li, Wei (2002), "Measuring Corruption under China's Dual-Track System," mimeo, Darden Graduate School of Business Administration, University of Virginia.

Lin, Justin Yifu, Fang Cai, and Zhou Li (1996), The China Miracle: Development strategy and economic reform, Hong Kong, Chinese University Press.

Naughton, Barry (1994), "Chinese Institutional Innovation and Privatization from Below," American Economic Review, v84, n2, p.p. 266-270.

Perotti, Enrico (1995), "Credible Privatization," American Economic Review, v85, n4: 847859.

Roland, Gerard (2000), Transition and Economics: Politics, markets, and firms, Comparative Institutional Analysis, vol 2, Cambridge and London: MIT Press.

Schmidt, Klaus (1996), "The Costs and Benefits of Privatization: An Incomplete Contracts Approach," Journal of Law, Economics, and Organization v12, n1: 1-24.

Schmidt, Klaus (2000), "The Political Economy of Mass Privatization and the Risk of Expropriation," European Economic Review, v44, n2: 393-421.

Shleifer, Andrei (1998), "State versus Private Ownership," Journal of Economic Perspectives, v12, n4: 133-150.

Shleifer, Andrei and Robert Vishny (1993), "Corruption," Quarterly Journal of Economics, v108, n3, p.p. 599-617.

Shleifer, Andrei and Robert Vishny (1994), "Politicians and Firms," Quarterly Journal of Economics, v109, n4, p.p. 995-1025.

Sonobe, Tetsushi and Keijiro Otsuka (2003), "Productivity Effects of TVE privatization: The case of garment and metal casting enterprises in the greater yangtze river region," NBER working paper, n9621. 
Sun, Laixiang (2002), "Fading out of Local Government Ownership: recent ownership reform in China's Township and Village Enterprises," Economic System, v26, n3: 249-269.

Svejnar, Jan (2002), "Transition Economies: Performance and Challenges," Journal of Economic Perspectives, v16, n1: 3-28.

Tenev, Stoyan, Zhang, Chunlin, and Loup Brefort (2002), 'Corporate Governance and Enterprise Reform in China: Building the Institutions of Modern Markets, World Bank and the International Finance Corporation, Washington D.C..

Transition Newsletter (1995), "Anticorruption Crackdown in China," v6, n5-6, World Bank.

World Bank (1995), Bureaucrats in Business: the economics and politics of government ownership, Oxford, Oxford University Press.

Zinnes, Clifford, Yair Eilat, and Jeffery Sachs (2001), "Gains from Privatization in Transition Economies: Is "change of ownership" enough?", IMF Staff Papers, v48, n0 (Special issue): 146-170. 


\section{DAVIDSON INSTITUTE WORKING PAPER SERIES - Most Recent Papers}

The entire Working Paper Series may be downloaded free of charge at: www.wdi.bus.umich.edu

CURRENT AS OF 10/31/03

\begin{tabular}{|c|c|c|}
\hline Publication & Authors & Date \\
\hline No. 627: The Life Cycle of Government Ownership & Jiahua Che & Oct. 2003 \\
\hline $\begin{array}{l}\text { No. 626: Blocked Transition And Post-Socialist Transformation: Serbia } \\
\text { in the Nineties }\end{array}$ & Silvano Bolcic & Oct. 2003 \\
\hline $\begin{array}{l}\text { No. 625: Generalizing the Causal Effect of Fertility on Female Labor } \\
\text { Supply }\end{array}$ & $\begin{array}{l}\text { Guillermo Cruces and Sebastian } \\
\text { Galiani }\end{array}$ & Oct. 2003 \\
\hline $\begin{array}{l}\text { No. 624: The Allocation and Monitoring Role of Capital Markets: } \\
\text { Theory and International Evidence }\end{array}$ & Solomon Tadesse & Oct. 2003 \\
\hline No. 623: Firm-Specific Variation and Openness in Emerging Markets & $\begin{array}{l}\text { Kan Li, Randall Morck, Fan Yang } \\
\text { and Bernard Yeung }\end{array}$ & Oct. 2003 \\
\hline $\begin{array}{l}\text { No. 622: Exchange Rate Regimes and Volatility: Comparison of the } \\
\text { Snake and Visegrad }\end{array}$ & $\begin{array}{l}\text { Juraj Valachy and Evžen } \\
\text { Kočenda }\end{array}$ & Oct. 2003 \\
\hline $\begin{array}{l}\text { No. 621: Do Market Pressures Induce Economic Efficiency?: The Case } \\
\text { of Slovenian Manufacturing, 1994-2001 }\end{array}$ & $\begin{array}{l}\text { Peter F. Orazem and Milan } \\
\text { Vodopivec }\end{array}$ & Oct. 2003 \\
\hline $\begin{array}{l}\text { No. 620: Compensating Differentials in Emerging Labor and Housing } \\
\text { Markets: Estimates of Quality of Life in Russian Cities }\end{array}$ & $\begin{array}{l}\text { Mark C. Berger, Glenn C. } \\
\text { Blomquist and Klara Sabirianova } \\
\text { Peter }\end{array}$ & Oct. 2003 \\
\hline $\begin{array}{l}\text { No. 619: Are Foreign Banks Bad for Development Even If They Are } \\
\text { Efficient? Evidence from the Indian Banking Sector }\end{array}$ & $\begin{array}{l}\text { Sumon Bhaumik and Jenifer } \\
\text { Piesse }\end{array}$ & Oct. 2003 \\
\hline No. 618: The Echo of Job Displacement & $\begin{array}{l}\text { Marcus Eliason and Donald } \\
\text { Storrie }\end{array}$ & Oct. 2003 \\
\hline No. 617: Deposit Insurance During Accession EU Ac & $\begin{array}{l}\text { Nikolay Nenovsky and Kalina } \\
\text { Dimitrova }\end{array}$ & Oct. 2003 \\
\hline $\begin{array}{l}\text { No. 616: Skill-Biased Transition: The Role of Markets, Institutions, and } \\
\text { Technological Change }\end{array}$ & Klara Sabirianova Peter & Oct. 2003 \\
\hline $\begin{array}{l}\text { No. 615: Initial Conditions, Institutional Dynamics and Economic } \\
\text { Performance: Evidence from the American States }\end{array}$ & Daniel Berkowitz and Karen Clay & Sept. 2003 \\
\hline $\begin{array}{l}\text { No. 614: Labor Market Dynamics and Wage Losses of Displaced } \\
\text { Workers in France and the United States }\end{array}$ & Arnaud Lefranc & Sept. 2003 \\
\hline No. 613: Firm Size Distribution and EPL in Italy & $\begin{array}{l}\text { Fabiano Schivardi and Roberto } \\
\text { Torrini }\end{array}$ & Sept. 2003 \\
\hline $\begin{array}{l}\text { No. 612: The Effect of Employee Involvment on Firm Performance: } \\
\text { Evidence from an Econometric Case Study }\end{array}$ & Derek C. Jones and Takao Kato & Sept. 2003 \\
\hline No. 611: Working Inflow, Outflow, and Churning & $\begin{array}{l}\text { Pekka Ilmakunnas and Mika } \\
\text { Maliranta } \\
\end{array}$ & Sept. 2003 \\
\hline $\begin{array}{l}\text { No. 610: Signaling in The Labor Market: New Evidence On Layoffs, } \\
\text { and Plant Closings }\end{array}$ & Nuria Rodriguez-Planas & Sept. 2003 \\
\hline $\begin{array}{l}\text { No. 609: Job Flows and Establishment Characteristics: Variations } \\
\text { Across U.S. Metropolitan Areas }\end{array}$ & R. Jason Faberman & Sept. 2003 \\
\hline No. 608: Dowry and Intrahousehold Bargaining: Evidence from China & Philip H. Brown & Sept. 2003 \\
\hline $\begin{array}{l}\text { No. 607: Policy Regime Change and Corporate Credit in Bulgaria: } \\
\text { Asymmetric Supply and Demand Responses }\end{array}$ & $\begin{array}{l}\text { Rumen Dobrinsky and Nikola } \\
\text { Markov }\end{array}$ & Sept. 2003 \\
\hline $\begin{array}{l}\text { No. 606: Corporate Performance and Market Structure During } \\
\text { Transition in Hungary }\end{array}$ & László Halpern and Gábor Kõrösi & Aug. 2003 \\
\hline $\begin{array}{l}\text { No. 605: Culture Rules: The Foundations of the Rule of Law and Other } \\
\text { Norms of Governance }\end{array}$ & $\begin{array}{l}\text { Amir N. Licht, Chanan } \\
\text { Goldschmidt, and Shalom H. } \\
\text { Schwartz }\end{array}$ & Aug. 2003 \\
\hline No. 604: Institutional Subversion: Evidence from Russian Regions & $\begin{array}{l}\text { Irina Slinko, Evgeny Yakovlev, } \\
\text { and Ekaterina Zhuravskaya }\end{array}$ & Aug. 2003 \\
\hline $\begin{array}{l}\text { No. 603: The Effects of Privitzation and International Competitive } \\
\text { Pressure on Firms' Price-Cost Margins: Micro Evidence from Emerging } \\
\text { Economics }\end{array}$ & $\begin{array}{l}\text { Jozef Konings, Patrick Van } \\
\text { Cayseele and Frederic Warzynski }\end{array}$ & Aug. 2003 \\
\hline No. 602: The Usefulness of Corruptible Elections & $\begin{array}{l}\text { Loren Brandt and Matthew } \\
\text { Turner }\end{array}$ & Aug. 2003 \\
\hline
\end{tabular}

